\title{
BURMISTRZ SIEDEMNASTOWIECZNEJ WARSZAWY KAROL ZABRZESKI I JEGO KSIĘGOZBIÓR
}

\author{
Pamięci Pani Doktor \\ Marii Sipayto
}

W Bibliotece Uniwersyteckiej w Warszawie (skrót: BUW) od ponad trzydziestu lat prowadzone pod kierunkiem dr Marii Sipayło badania proweniencyjne zaowocowały wyłonieniem wielu interesujących staropolskich księgozbiorów. Jedna z tych kolekcji należała do mało dotychczas znanego przedstawiciela mieszczaństwa warszawskiego - Karola Zabrzeskiego.

\section{1. ŻYCIE}

Wiadomości o życiu Karola Zabrzeskiego są jedynie fragmentaryczne. Z ocalałych z pożogi wojennej archiwaliów dość dużo materiału, chociaż o ograniczonym zakresie, zawierają księgi warszawskiej parafii św. Jana, nieco informacji dostarcza też szczęśliwie zachowana Metryka Koronna i akta Rady Miejskiej Starej Warszawy. Na wiele istotnych pytań dotyczących życia Karola Zabrzeskiego nie znamy jednak odpowiedzi.

Można przypuszczać, że urodził się w Warszawie, z którą związany był przez co najmniej 25 lat swego życia. Pochodził zapewne ze średniozamożnego mieszczaństwa. Wśród mieszkańców XVII-wiecznej Starej Warszawy spotykamy m.in. Jakuba Zabrzeskiego - krawca, Sebastiana Zabrzeskiego-notariusza ${ }^{1}$. Nazwisko to przewija się także $w$ dokumentach dotyczących właścicieli drobnych nieruchomości stołecznego grodu, nie ma go natomiast wśród przedstawicieli władz miejskich i patrycjatu Warszawy I połowy XVII w.

Najwcześniejsza znana nam wzmianka o Karolu Zabrzeskim pochodzi z 1642 r.: wówczas to otrzymał w Akademii Krakowskiej tytuł bakałarza, co rejestruje Liber promotionum Akademii pod datą 5 III 1642 ${ }^{2}$. Na podstawie tej informacji można przypuszczać, że urodził się w początku lat 20-tych XVII wieku, ale mogło to mieć miejsce i o kilka lat wcześniej (wiek studentów Akademii był bardzo zróżnicowany). W 1644 r. w okolicznościowym druczku związanym z Akademią Krakowską ${ }^{3}$ wśród wierszowanych gratulacji Ignacego Szlachetki dla czterdziestu „secundae laureae (tj. magisterium) in artibus et philosoph(ia) candidatis" spotykamy utwór poświęcony Zabreskiemu.

W letnim semestrze 1644 młody magister podjął i prowadził przez pół roku wyklady na Wydziale Filozoficznym jako extraneus non de facultate ${ }^{4}$. Tę typowo 
rozpoczętą karierę uniwersytecką wkrótce jednak porzucił, w każdym razie brakuje dalszych wzmianek na ten temat.

Nie mamy też wiadomości o Zabrzeskim pochodzących z dziesięciolecia 1645-1654. Być może nie było go wtedy w Warszawie, bo np. w ówczesnych księgach parafii św. Jana nie spotykamy jego nazwiska, choć często występuje tam ono począwszy od 1655 r. Zapis wikariusza parafii z 11 III 1955 r. informuje, że w dniu tym Zabrzeski podawał do chrztu dziecko kupca Krzysztofa Fibiga ${ }^{5}$. Później co roku mniej więcej (z przenwą na okres wojen szwedzkich) trzymał do chrztu dzieci lub występował jako świadek podczas ceremonii ślubnych przedstawicieli różnych familii mieszczańskich, najpierw o mniej znanych, z czasem o coraz znaczniejszych nazwiskach: Dzianottowie, Falkowiczowie, Witthoffowie ${ }^{6}$. Swoja pasierbicę Justynę Teściankę wydał za znanego architekta Józefa Fontanę ${ }^{7}$.

W 1655 r. Zabrzeski pracuje już zawodowo jako prawnik, zatrudniony w konsystorzu warszawskim. W tymże roku w zapisie w Liber baptisatorum nazwany jest „iurista spiritualis"8. Od tego momentu możemy obserwować dość szybki postęp jego kariery zawodowej i społecznej.

W II polowie XVII w. na skutek działań wojennych i różnego rodzaju klęsk podupada wiele starych rodów warszawskich i dochodzą do głosu nowi ludzie. Najbardziej dynamiczne jednostki awansuja do stanu szlacheckiego, szczególnie za Jana Kazimierza częste są nobilitacje mieszczan. Nie był to, jak wykazała historia, najszczęśliwszy kierunek rozwoju stanu mieszczańskiego, ale prerogatywy szlacheckie nęciły „sławetnych". Tą drogą pójdzie w przyszłości i Zabrzeski.

W osiągnięciu sukcesów życiowych wydatnie pomogły mu dwa korzystnie zawarte małżeństwa. Nieznana jest data ślubu z pierwszą żoną, Zofią z Gomerów, wdową po obywatelu Warszawy Antonim Teście, włoskiego pochodzenia kupcu winnym. Wychodząc za Zabrzeskiego miała ona już czworo dzieci z pierwszego małżeństwa ${ }^{9}$. Ślub odbył się prawdopodobnie między rokiem 1654 a $1657^{10}$. Księgi parafii św. Jana nie zarejestrowały tego ślubu, ale zważywaszy powiazzania dworskie ojca Zofii, muzyka królewskiego Jana Gomera, uroczystość mogła mieć miejsce w którejś z kaplic zamkowych.

Przez małżeństwo wchodzi Zabrzeski w krąg patrycjatu miejskiego. Staje się właścicielem dobrze zlokalizowanej, bo blisko Rynku, kamienicy przy ulicy Świętojańskiej ${ }^{11}$. Dzięki teściowi zyskuje kontakty z dworem królewskim, co zaowocuje w przyszłości pracą w królewskiej kancelarii.

Na razie jednak pracuje w konsystorzu. W 1659 r. w ksieggach parafialnych zwany jest "notarius in Consistorio Spirituali Vars(aviensi)", w 1661 - "notarius apostolicus publicus et Consistorii Vars(aviensis)". Tytuł "notarius Consistorii Vars(aviensis)" nosi jeszcze w $1666 r^{12}$

W roku 1665 osiąga Zabrzeski najwyższą godność w karierze samorządowej - zostaje obrany burmistrzem Starej Warszawy. Ten sam zaszczyt spotyka go w latach 1666 i 1669 . Dowodzi to, że jego pozycja społeczna była już wtedy wysoka, gdyż burmistrzowie w drugiej połowie XVII w. wywodzili się zazwyczaj z najwyższego, bardzo zamożnego patrycjatu. Urząd pociagał ze sobą koszty na reprezentację, a uposażenie burmistrza w czasach Jana Kazimierza było symboliczne ${ }^{13}$. 
W 1669 r. Zabrzeski jako burmistrz przewodniczył delegacji Rady Miejskiej udającej się na koronację Michała Wiśniowieckiego do Krakowa ${ }^{14}$. Delegacja otrzymała wówczas potwierdzenie dotychczasowych praw i przywilejów Starej Warszawy.

W roku koronacji Michała jest już ponownie żonaty - tym razem z Barbarą Giżanką, pochodzącą z potężnej warszawskiej rodziny patrycjuszkowskiej, nobilitowanej za Zygmunta III. Wchodząc do tej familii, robi Zabrzeski kolejny krok wzwyż w swojej karierze: nosi już wówczas tytuł „Sacrae Regiae Maiestatis secretarius”. Piastuje urząd sekretarza kancelarii królewskiej podczas panowania trzech kolejnych monarchów: Jana Kazimierza, Michała i Jana III ${ }^{15}$. Nie zrywa jednak kontaktów z kuria: w latach 1675-1676 jest audytorem nuncjusza papieskiego Franciszka Martelliego ${ }^{16}$.

Na sejmie koronacyjnym 2 II - 4 IV 1676 Zabrzeski zostaje nobilitowany wśród osób "od wielmożnych hetmanów koronnych zaleconych", jako jeden z chorą$z ̇ y c h^{17}$. Herb Zabrzeskich nie jest znany ${ }^{18}$. Nie wiadomo także, kiedy Karol otrzymał tytuł cześnika trembowelskiego, choć tytuł ten jest wypisany na karcie tytułowej każdej książki z jego kolekcji ${ }^{19}$. Tego tytułu, pisząc o Zabrzeskim, używa również Erndtel w swojej pracy o Warszawie 20 .

Nowokreowany szlachcic dba o swoje prywatne interesy. W Metryce Koronnej pod datą 30 I 1677 znajdujemy informacje, iż Karol Zabrzeski, sekretarz królewski, za zasługi wobec dworu otrzymuje zwolnienie od obowiązu kwaterowania gości dworskich w kamienicy zwanej tu "Gomerańska", należącej do niego i jego żony, urodzonej Barbary Giżanki ${ }^{21}$. Tamże pod datą 7 X 1677 widnieje zapis, iż urodzony Karol Zabrzeski otrzymuje prawo ,iuris caduci" po zmarłym uczonym Piotrze Pirocie, zapewne krewnym jednego z członków Rady Miejskiej o tym samym nazwisku ${ }^{22}$.

W kancelarii koronnej sekretarzowi Zabrzeskiemu powierza się dość poważne sprawy. 11IV 1673 r. Jan Tański, instygator koronny, mianuje Karola Zabrzeskiego swoim plenipotentem w Nuncjaturze Apostolskiej w sprawie sporu opactwa cystersów w Koronowie z biskupem Kryszztofem Żegockim ${ }^{23}$. 8 IV 1679 r. Zabrzeski zostaje wyznaczony przez króla do przeprowadzenia cesji królewskich wsi Gotartów i Sobieścieszno w starostwie warszawskim, będących w dożywociu Jana Zaleskiego, kuchmistrza koronnego, na rzecz syna tegoż kuchmistrza - Jana Stanisława ${ }^{24}$. Jest to ostatnia odnaleziona przez nas wzmianka o Zabrzeskim zarejestrowana za jego życia. 20 IX 1683 r. Rada Miejska Starej Warszawy podejmuje już decyzje w sprawie kamienicy „successorum olim G[e]n[ero]si Zabrzeski S[acr]ae R[egi]ae M[aiesta]tis secretarii" ${ }^{25}$.

Z uzyskanych okruchów informacji można więc wnosić, że Karol Zabrzeski mieszkał do końcażycia wWarszawie, otoczony licznym gronem pasierbów i własnych dzieci z dwu małżeństw, pracując w konsystorzu i w kancelarii królewskiej. Intensywnie udzielał się towarzysko, o czym świadczy jego udział w chrztach, ślubach i pogrzebach, oraz publicznie, na co wskazuje długoletnia działalność w Radzie Miejskiej ${ }^{26}$.

Ponadto gromadził książki.

\section{WCZEŚNIEJSI WŁAŚCICIELE KSIĘGOZBIORU}

Wybitny znawca starej książki i problematyki badań proweniencyjnych Kazimierz Piekarski - był zdania, że tylko istnienie superekslibrisów właściwych, a 
więc odbitych z jednego tloku na specjalne zamówienie właściciela, potwierdza istnienie większych $i$ ciekawszych bibliotek $w$ dawnej Polsce $e^{27}$. Kontynuatorka tych badań - Maria Sipayło - stwierdza natomiast, iż także duże i interesujące księgozbiory bywały niejednokrotnie znaczone superekslibrisami składanymi, czyli introligatorskimi ${ }^{28}$. Wszelako postępująca rejestracja znaków własnościowych w naszych bibliotekach wykazuje, iż ciekawe nieraz i duże kolekcje staropolskie w ogóle nie miały znaków własnościowych w postaci superekslibrisu czy ekslibrisu i były znaczone jedynie zapisami odręcznymi ${ }^{29}$. Tak właśnie przedstawia się omawiana obecnie biblioteka Karola Zabrzeskiego.

Zabrzeski nie miał bowiem własnego superekslibrisu ani ekslibrisu. Jego odręczny zapis własnościowy na kartach tytułowych posiadanych ksiażek jest bardzo charakterystyczny i prawie zawsze wyglada tak samo: „Sum Caroli Zabrzeski" wypisane wyrobioną, XVII-wieczną ręką, znacznych rozmiarów literami. Tekst ten zwykle otoczony jest dopiskami również XVII-wiecznej ręki: przed inskrypcją Zabrzeskiego dodawano mianowicie „Ex donatione Generosi” (lub po prostu „G"), a po nazwisku, w mniejszym lub większym skrócie, „Pincernae Trebovliensis” (lub "Trebovlensis"), na końcu zaś zapisu umieszczano wezwanie: „oretur pro eo". Dopiski te pochodzą od bibliotekarza klasztoru karmelitów bosych w Warszawie, bowiem w tym klasztorze przechowywany był księgozbiór Zabrzeskiego do momentu kasaty zakonu po Powstaniu Styczniowym. Na kartach tytułowych jego książek znajduje się zapis proweniencyjny klasztoru: „Conventus Varsaviensis Carmelitarum Discalceatorum", a na wewnętrznej stronie górnej okładki sygnatura biblioteki klasztornej w charakterystycznym prostokąciku.

W kilku woluminach istnieje wyłącznie zapis karmelitów informujący o donacji Zabrzeskiego, w kilku innych zapis kolekcjonera jest pozbawiony dopisków karmelitów. Te drugie, to pozycje, które za życia Zabrzeskiego lub po jego śmierci zostały przekazane $w$ inne ręce i nie dostały się karmelitom. Trafily one jednak $w$ końcu również do BUW albo do biblioteki Seminarium Duchownego w Warszawie.

Notatek robionych ręką Zabrzeskiego w książkach jest niewiele. Bywają to marginalia typu indeksowego, sentencje lub uwagi na wyklejkach dotyczące sposobu zdobycia książki ${ }^{30}$. Pozycje z takimi notatkami stanowią nie więcej niż $10 \%$ księgozbioru. Wiele książek pozbawionych jest jakichkolwiek zapisków.

Oprawy książek pochodzą w przeważającej większości z XVI i XVII w., są przeważnie skromne, choć zdarzają się i bardzo ozdobne. Dość dużo spośród nich to pospolite niemieckie oprawy z bialej świńskiej skóry na desce lub kartonie, ze ślepymi tloczeniami. Posiadał też Zabrzeski pewną liczbę ladnych opraw ze skóry cielęcej lub wołowej, ze ślepymi i złoconymi tłoczeniami i oryginalnymi plakietami. Piękna jest np. oprawa dzieła Capivaccia Methodus anatomica: okładziny z brunatnej skóry obciągnięte na kartonie są ozdobione w rogach małymi tłoczkami w kształcie lilijek, w środku wyciśnięto plakietę z motywem geometryczno-wstęgowym przeplatającym się z kwiatowym, przy czym nie sam ornament, jak zwykle bywa, lecz tho plakiety i narożników jest złocone ${ }^{31}$. Spotykamy też oprawy polskie z charakterystycznym „radełkiem jagiellońskim"32.

Wśród okładzin ze skóry świńskiej na uwagę zasługuje oprawa dzieł wszystkich Gilberta Cognata Nazarena. Jest to przykład tzw. oprawy mniszej: okładka 
z tektury została obciągnięta do połowy skórą świńską z niewielką ilością tłoczeń, których kompozycja wykazuje wyraźnie kompletność oprawy w takiej wersji ${ }^{33}$.

Ponad połowa opraw to pergamin, przeważnie biały, niekiedy barwiony, utwardzony kartonem lub papierem - oprawa lekka i trwala, bardzo popularna w Europie XVII w. Niektóre z tak oprawionych książek były - wydaje się - kierowane do introligatora na zlecenie Zabrzeskiego. W jednej z publikacji widnieje na wyklejce uwaga wypisana prawdopodobnie jego ręką: „Comparatus Warssauiae in sexternis f[lo]r[enis] 4 gr[ossis] 15 A[nn]o 1655 [1635?] die 21 9bris". Ponadto na grzbiecie również, wydaje się, jego ręką wypisany jest tytuł $i$ autor dzieła. Należy więc sądzić, że po zakupieniu książki w arkuszach sam oddał ją do oprawy ${ }^{34}$. Tak oprawionych i opisanych na grzbiecie książek jest więcej.

Większą jednak część omawianej kolekcji burmistrz nabył w postaci już ukształtowanej przez poprzednich posiadaczy. Najpiękniejsze oprawy mają właśnie książki odziedziczone po znanych kolekcjonerach: królu Zygmuncie Auguście, Melchiorze Krupku, Adamie Tussinusie czy Mikołaju Żórawskim.

Na czoło poprzednich posiadaczy mysuwa się - nie tylko z powodu piastowanej godności - ostatni monarcha z dynastii Jagiellonów - Zygmunt August. Zabrzeski miał aż 6 woluminów z księgozbioru królewskiego, pięknie oprawionych w brunatną, obciągniętą na desce skórę, z wytłoczonymi herbami Rzeczypospolitej j charakterystyczną inskrypcją ${ }^{35}$. Zawierają one 10 dzieł o bardzo szerokim wachlarzu tematycznym. Reprezentowana jest tu medycyna, filologia, historia, geografia, filozofia. Nie wiadomo, jakim sposobem zdobył Zabrzeski pięć spośród owych sześciu woluminów. Tylko w przypadku klocka zawierającego 4 dziełka medyczne droga książki od króla do Zabrzeskiego jest łatwa do prześledzenia. Pierwszym po królu w lańcuchu właścicieli jest Hieronim z Poznania, „chirurgus Serenissimae Reginae Poloniae Annae Jagielloniae", jak sam się podpisał na karcie tytulowej omawianego tomu. Od Anny Jagiellonki też zapewne tom ów otrzymał w darze. Następnie książka przeszła w ręce Jana Klemensa Radziwina, znanego lekarza warszawskiego z początku XVII w., właściciela dużego księgozbioru. Radziwin był zięciem Hieronima z Poznania, pewnie otrzymał więc książę jako dar teścia lub spadek po nim. Zabrzeski, również przedstawiciel patrycjatu warszawskiego, chociaż żyjący o pokolenie później, otrzymał ja prawdopodobnie od potomków Radziwina.

Wśród pozostałych właścicieli bibliotek, których księgi znalazły się w księgozbiorze burzmistrza Starej Warszawy, dwie najwyraźniejsze grupy stanowią profesorowie Akademii Krakowskiej i lekarze.

Profesorowie, to na ogół posiadacze dużych, znanych literaturze fachowej księgozbiorów: czterej z nich mieli własne superekslibrisy. Do grupy też należa: Adam Tussinus, Jan Leopolita, Stanistaw Grzepski, Sylwester Roguski, Walenty Fontanus, Jan Fox, Stanisław Pudłowski, Adam Draski, Mikołaj Żórawski ${ }^{36}$.

Po astronomie Adamie z Tuszyna (Tussinusie), bibliofilu, właścicielu co najmniej trzech superekslibrisów, znajdują się w zbiorze Zabrzeskiego dwie książk: „Colloquia familiaria” Erazma z Rotterdamu ${ }^{37}$ i piąta część dzieł wszystkich Galena po grecku w pięknym bazylejskim wydaniu Cratandra ${ }^{38}$. Na obydwu odciśnięty jest superekslibris $11^{39}$. 
Dzieła Homera w oryginale, własność Jana Leopolity, teologa, egzegety Pisma św., redaktora pienwszego przekładu Biblii na język polski, są pięknie oprawione w brunatną skórę na desce, ze ślepymi tłoczeniami. W górnej części przedniej okładziny wytłoczony jest zapis sugerujący, że okrywa ona dzieła Melanchtona. Czyżby więc zmieniono przeznaczenie tej oprawy? Poniżej wybito: I/OANNES/ LE/OPOLITA/ i złotern wytłoczono superekslibris Leopolity z Ganimedem na orle ${ }^{40}$. (Superekslibris nie jest dobrze wkomponowany w tło okładki, robi wrażenie dodanego później).

Stanisław Grzepski, filolog, matematyk, popularyzator nauki, zgromadził piękną bibliotekę dzieł pisarzy starogreckich i bizantyńskich. Zabrzeski miał po nim mowy Diona Chrysostoma ${ }^{41}$ ze skromnym literowym superekslibrisem: na pospolitej oprawie ze świńskiej skóry ze ślepymi toczeniami widnieje dość nierówno odciśnięty oddzielnymi łłoczkami, niegdyś złoty, dziś sczerniały napis „Stanislai Grzepsii”.

O profesorze medycyny Sylwestrze Roguskim będzie mowa poniżej.

Do Ślązaka Walentego Fontanusa, lekarza, znanego astronoma i astrologa należalo aż 6 publikacji. Cztery z nich to dzieła religijne, m.in. odziedziczona po biskupie Janie Latalskim Biblia we wczesnoszesnastowiecznym strasburskim wydaniu $^{42}$. Poezje Katulla, Tibulla i Propercjusza dostały się Zabrzeskiemu po profesorze prawa - Janie Foksie ${ }^{43}$.

Stanisław Pudłowski - matematyk, fizyk, astronom z wykształcenia i zamiłowania, a prawnik tylko z wykształcenia, był właścicielem dużego i nowoczesnego księgozbioru, jednego z najwyżej cenionych w Akademii w XVI w. Był on drugim wlaścicielem (pienwszy, oznaczony inicjałami IPI, pozostał niezidentyfikowany) bardzo ciekawego klocka introligatorskiego zawierającego 5 pozycji, z których szczególnie zwraca uwage dziełko znanego humanisty niemieckiego, Jana Reuchlina - De arte cabalistica ${ }^{44}$.

Po Adamie Draskim, profesorze wydziału artium, dostały się Zabrzeskiemu pisma Grzegorza z Nazjanzu (tekst grecki) ${ }^{45}$. Wcześniej należały one do studenta Akademii Krakowskiej Jana Wierzbickiego.

Mikołaj Żórawski, „vir trilinguis" - znawca greki, taciny i hebrajskiego - miał superekslibris dotychczas, wydaje się, nie notowany przez badaczy. Na okładce dzieła Middendorffa Officiorum scholasticorum libri duo znajduje się starannie wytłoczony herb Poraj i podpis "Nicolaus Źórawski"46. Źórawski nie byl szlachcicem, lecz synem lubelskiego pisarza miejskiego ${ }^{47}$, wystylizował więc na herb motyw kwiatowy, popularny w superekslibrisach profesorów krakowskich ${ }^{48}$.

O profesorach - lekarzach pisał L. Hajdukiewicz: „Szczególnie liczny udział w tym renesansie profesorskiego zbieractwa mają medycy, przeznaczający część swych dochodów z zyskownej praktyki lekarskiej na stwórzenie bibliotek odznaczających się tak dbałością o zewnętrzną formę, jak i zamiłowaniem do piśmiennictwa humanistycznego i literatury klasycznej"49 "Lekarze o niższych stopniach naukowych także mieli często rozbudzone przez studia zamiłowanie do ksiąg, a dzięki praktyce - znaczne fundusze na ich zakup. W księgozbiorze Zabrzeskiego grupę lekarzy reprezentują: profesor medycyny Sylwester Roguski, ojciec i syn Schneebergerowie, Johann Crato, Hieronim z Poznania, Jan Radziwin, Petrus Praetorius, Albert Rubiński i Andrzej Pograbka. 
Losy i książki profesora Akademii Krakowskiej - Sylwestra Roguskiego astronoma, matematyka i praktykujacego lekarza splatają się z losem dwóch pokoleń Schneebergerów, lekarzy krakowskich. Roguski, lekarz biskupa Stanisława Karnkowskiego, a potem Zygmunta Augusta i Anny Jagiellonki, miał duże znajomości w krakowskich kręgach medycznych, m.in. zaprzyjaźniony był z ojcem i synem Schneebergerami.

Antoni Schneeberger starszy (1530-1581), urodzony w Zurichu, uczeń Konrada Gesnera, osiadł w Krakowie i tu praktykowal jako lekarz. Z Roguskim łączyła go długoletnia znajomość, a nawet przyjaźń. Jego syn, również Antoni, uprawiający także zawód medyka, przyjaźń tę jeszcze pogłębił. Poza wzmiankami w literaturze fachowej świadczą o tym zachowane książki. Z trzech druków, jakie po Sylwestrze Roguskim znajdują się w Bibliotece Uniwersyteckiej w Warszawie, wszystkie były później własnością Antoniego Schneebergera młodszego. W jednym z nich, Geografii Ptolemeusza, Roguski używa w stosunku do Schneebergera zwrotu „pronepoti et clienti suo" ${ }^{50}$. Jedna z tych książek przeszła później na własność Zabrzeskiego, a mianowicie E.Reinholda Prutenicae tabulae coelestium motuum ${ }^{51}$.

W zbiorach Zabrzeskiego znalazły się również po jednej książki należące do ojca i syna Schneebergerów, nie mające jako poprzednego właściciela Roguskiego. Klocek zawierający Onomasticon Polluxa i dziełko Lycophrona, na odwrocie karty tytułowej pierwszej pozycji ma nalepiony ekslibris Antoniego Schneebergera starszego, a na karcie tytułowej odręczny zapis: „Antonii Schneebergeri, Tigurini, Helueti, medici..." ${ }^{52}$ (Jego syn, jako urodzony w Polsce, podpisywal się czasem „Helvetiopolonus") ${ }^{53}$.

Na okladce książki włoskiego lekarza Albertina Bottoniego o chorobach kobiecych znajduje się superekslibris Antoniego Schneebergera syna ${ }^{54}$.

Po jego śmierci gromadzony przez dwa pokolenia księgozbiór uległ rozproszeniu ${ }^{55}$.

Johann Crato von Kraftheim, lekarz miejski we Wrocławiu, żyjący w latach 1519-1585, miał duży księgozbiór, a niektóre swe książki znaczył superekslibrisem. Książki z kolekcji Cratona to publikacje współczesne mu, o bardzo szerokim zakresie tematycznym, świadczące o rozległych zainteresowaniach wlaściciela. Istotnie, Crato nie tylko zajmował się praktyką lekarska, ale również wiele pisał i publikował. Znane są jego dzieła o tematyce medycznej i teologiczno-moralnej. W bibliotece Zabrzeskiego dochowało się po nim 9 dzieł w 5 woluminach. Interesująco omówiła je pod względem proweniencyjnym $K$. Sokołowska-Grzeszczyk ${ }^{56}$.

O Hieronimie z Poznania, właścicielu ciekawego klocka pochodzącego z biblioteki Zygmunta Augusta, była już mowa powyżej.

Petrus Praetorius, dopisujący do swego nazwiska "Witebergensis”, był może krewnym Piotra Praetoriusa, teologa krypto-kalwińskiego, który długie lata wykladał w Wittenberdze ${ }^{57}$. Podpisał się na dziele Dioskoridesa De materia medica libri ${ }^{58}$.

Albert Rubiński, to zapewne asesor nacji polskiej w Padwie w latach $1628 \mathrm{i}$ $1629^{59}$. Posiadał on Galesina Dittionario overo tesoro della lingua volgare latina ${ }^{60}$. Jest to słownik języka włoskiego, publikacja wyjątkowa u Zabrzeskiego, który zdawał się nie interesować językami nowożytnymi. 
Jeszcze jeden medyk, reprezentowany w zbiorach Zabrzeskiego, to Andrzej Pograbka, lekarz i kartograf, zmarły w $1602 \mathrm{r}$. Miał on Nowy Testament po grecku $w$ bazylejskim wydaniu Frobena ${ }^{61}$. Drugim właścicielem tej książki była również znana osobistość polskiego świata naukowego: Sebastian z Felsztyna - kompozytor, muzykolog, autor kilku traktatów. Na karcie tytułowej dzieła znajduje się, napisana niezbyt poprawną greką, informacja, iż Sebastian z Felsztyna kupił tę książkę w 1563 r. od Andrzeja Pograbiusa w Przemyślu. Zgadza się to z danymi z życiorysu Pograbki: w 1568 r. wyjechał on na studia do Włoch na koszt przemyskiego lekarza Jakuba z Uścia.

Wśród dawnych właścicieli ksiąg należących później do Zabrzeskiego nazwiska szlacheckie pojawiają się prawie równie często jak mieszczańskie, z pewną przewagą tych ostatnich.

Wśród przedstawicieli patrycjatu miejskiego, głównie Krakowa i Warszawy, bo z tymi miastami najbardziej związany był Zabrzeski, spotykamy m.in. nazwiska Fuggerów (Fukierów), Aychlerów, Hemplów, a więc przedstawicieli rodów mających szlachectwo zagraniczne, potwierdzone potem w Rzeczypospolitej, jak też rodów, które niebawem szlachectwo polskie otrzymaja.

Stefan Aychler, mieszczanin krakowski, syn Stanistawa, humanisty, prawnika i kupca krakowskiego, brat Erazma, znanego dzialacza protestanckiego, odziedziczył po ojcu cały prawie jego księgozbiór ${ }^{62}$. Jest on podpisany na karcie tytułowej trzeciej części kroniki Cariona: „Steph/ani/ Aychleri ab Aychenbaum Eq/uitis/ Germanopol/oni/"63.

W księgozbiorze Zabrzeskiego znajdowała się również książka przedstawiciela znanej rodziny Fuggerów - Kryszztofa Fuggera. Fuggerowie, przybyli do Polski z Augsburga, posiadali szlachectwo niemieckie. Korzystając w Polsce z praw miejskich i obywatelstwa miejskiego, formalnie $w$ XVI i XVII w. zaliczani byli w poczet mieszczan. W końcu XVII w. otrzymali indygenat ${ }^{64}$. Ulryk Fugger, przedstawiciel galęzi krakowskiej, miał dużą bibliotekę, przekazaną po jego śmierci dominikanom w Augsburgu. O Krzysztofie nic bliższego nie wiadomo. Podpisak się on lakonicznie: „Ex libris Christophori Fuggeri' ${ }^{65}$; dukt i krój pisma wy daje się XVI-wieczny.

$\mathrm{Na}$ górnej okładzinie bardzo skromnie oprawionej Historii Herodota znajdują się wythoczone na pergaminie litery "G H G" $z$ datą $1609^{66}$. Kryptonim ten jest rozwiązany na karcie tytułowej ksiażki, gdzie wyraźnym, wyrobionym, XVI-wiecznym charakterem pisma widnieje: „Godfridus Hempelus Gorlicius Sil/esius/”. Być może jest to Gottried Hempel, kaznodzieja z Rostersdorf (obecnie Trzęsów na Śląsku), autor zbioru wierszy wydanych w $1650 \mathrm{r}^{67}$

Wśród książek przedstawicieli stanu szlacheckiego znajdujemy w księgozbiorze Karola Zabrzeskiego m.in. jeden z trzech w jego kolekcji egzemplarzy Historii etiopskiej Heliodora ${ }^{68}$. Nosi on superekslibris Pawła Pszonki herbu Janina, studenta Akademii Krakowskiej w latach 1653-1654, autora ogłoszonych podczas studiów poematów religijnych ${ }^{69}$. Paweł Pszonka pochodził ze znanej rodziny małopolskiej, która wydała założycieli i działaczy słynnej Rzeczypospolitej Babińskiej.

Bezpośrednio natomiast z Rzeczpospolitą Babińską zwiazany był Mikołaj Ossoliński, kasztelan parnawski, padewczyk, zmarly ok. 1650 r. Był on przed Zabrzeskim właścicielem bardzo popularnego w swoim czasie dzieła lekarza Paola 
Giovia pt. „Historiarum sui temporis tomus", obejmującego dzieje Europy II połowy $\mathrm{XVI} w^{70} \mathrm{Na}$ tylnej okładzinie książki widnieje superekslibris introligatorski - herb Topór (Ossolińskich). Książkę tę przekazal Ossoliński, jak wynika z częściowo nieczytelnego zapisu proweniencyjnego, Jerzemu Mn/ischowi(?)/. W jaki sposób dostała się później Zabrzeskiemu - nie wiadomo.

Właścicielem pierwszego tomu popularnego czasopisma społeczno-literackiego "Mercurius Gallobelgicus” ${ }^{71}$ był Piotr Brochowski, „equitus/!/ Polonus". Może był to wojski sochaczewski, potem, w początku XVII w., podkomorzy zakroczymski, syn Jana, pieczętujący się herbem Prawdzic ${ }^{72}$.

Do ciekawszych postaci związanych z księgozbiorem Zabrzeskiego zaliczyć można także wenecjanina Jana Michała Brutusa, humanistę, historyka związanego z dworem Stefana Batorego. Był on właścicielem dwóch współoprawnych poematów dydaktycznych: Nikandra z Kolofonu o jadowitych wężach i sławnego astronomiczno-dydaktycznego poematu Aratusa ${ }^{73}$.

Genewskie grecko-łacińskie wydanie Nowego Testamentu oraz współoprawny z nim katechmizm należały do karmelity Wojciecha Czepiela ${ }^{74}$. Na karcie tytulowej Nowego Testamentu greckim alfabetem jest napisane: „Albertus Tschieoiele(!) Dalmates", a na karcie tytułowej katechmizmu - alfabetem lacińskim, siedemnastowieczną ręką „Albertus Tschiepieli”, inną ręką dopisano obok „Fr/ater/ Carmelita 1610 Polonus”, inną jeszcze „Dalmata Polonus”. Te nieskładne zapiski zawierają spory ładunek informacji o człowieku, o którym poza tym niezbyt wiele wiadomo: napisał dwa utwory poświęcone św. Marii Magdalenie Pazzi, zginą we Lwowie w 1648 r. z rąk Kozaków ${ }^{75}$.

Pierwszym właścicielem dzieła polskiego uczonego z XIII w. - Vitelona - poświęconego optyce ${ }^{76}$, był Melchior Krupek, przedstawiciel świeżo nobilitowanej (1515 r.) rodziny mieszczan krakowskich, słynny bibliofil. Oprawy książek Krupka charakteryzowały się wielkim podobieństwem do opraw Zygmunta Augusta. Piekarski cytuje dwie odmiany jego superekslibrisu; Zabrzeski ma egzemplarz z odmianą $1 \|^{77}$.

Prawdopodobnie do biskupa - humanisty Jana Latalskiego, wieloletniego pracodawcy Andrzeja Modrzewskiego - Frycza, należała grecka Biblia ${ }^{78}$, znajdująca się potem w posiadaniu Walentego Fontanusa, wspomnianego już profesora Akademii Krakowskiej. Na górnej okładce wytloczony jest herb Prawdzic, bardzo zatarty, powyżej umieszczono insygnia biskupie.

Wymienione wyżej postaci nie zamykają listy byłych wlaścicieli ksiaż̇ek Zabreskiego. Niektórych zapisów proweniencyjnych z różnych przyczyn nie można odczytać. Bywają one niewyraźne, wyblakłe, zatarte lub wydarte przez następnych posiadaczy ksiażek. O niektórych osobach trudno doszukać się jakichkolwiek informacji.

\section{DALSZE LOSY KSIĘGOZBIORU}

Księgozbiór Zabrzeskiego przekazany został, zapewne na mocy testamentu lub z inicjatywy spadkobierców, klasztorowi karmelitów bosych w Warszawie na Krakowskim Przedmieściu ${ }^{79}$. W którym roku tam wpłynął - nie wiadomo. Archiwum tego klasztoru, znajdujące się obecnie w Archiwum Archidiecezjalnym, zostało 
mocno uszczuplone z powodu zawieruchy wojennej. Jedyny poza książkami ślad kontaktów Zabrzeskiego z tym klasztorem stanowi wzmianka pochodząca z 1686 r. o zapisie pieniężnym w księdze przychodów i wydatków konwentu: „Ex censu a D. Zabreski flor/enis/ quingent/i/ quinquaginta........f.550." Była to kwota znaczna w porównaniu z innymi wymienionymi w księdze dotacjami ${ }^{80}$. Można więc sądzić, że kontakty rodziny Zabrzeskich z karmelitami były żywe i przekazanie księgozbioru klasztorowi nie bylo jedynym ich przejawem.

Księgozbiór wymieniony jest w znanej pracy lekarza nadwornego Augusta II, Chrystiana Henryka Erndtela, „Warsavia physice illustrata”, w rozdziale pierwszym - „De situ Warsaviae”, napisanym dla niego przez Józefa A. Załuskiego. Omawiając klasztor karmelitów bosych na Krakowskim Przedmieściu i jego nowe budynki, pisze on o bibliotece: „Prima huius bibliothecae fundamenta autem Patres, Zabreski cuidam, Nobili ex antiqua familia(!), Musarum filio et Patrono, Pincernae quondam Dręboliensi(!) in acceptis ferunt' ${ }^{181}$.

Księgozbiór Zabrzeskiego był podstawą i ozdobą biblioteki karmelitów do momentu kasaty zakonu w 1864 r. Po powstaniu styczniowym skasowano wiekszość warszawskich domów zakonnych, a ich biblioteki przeszly w gestię specjalnie powołanej komisji. Składała się ona z przedstawicieli Konsystorza Generalnego Królestwa Polskiego i Biblioteki Szkoły Głównej w Warszawie. Komisja ta rozdzieliła skonfiskowane księgozbiory między Seminarium Gtówne (wówczas Rzymsko-Katolicką Akademię Duchowna) i Bibliotekę Główną ${ }^{82}$. Trudno określić, według jakich kryteriów dokonano podziału. Zdecydowanie nie był to - jak powszechnie się uważa - podziar na książki religijne i świeckie. Być może do Seminarium kierowano tytuły, które już znajdowały się w książnicy Szkoły Głównej i - nie bacząc na całość proweniencyjną - porozbijano poszczególne kolekcje.

Powody i sposób przejścia książek Zabrzeskiego wraz z częścią księgozbioru karmelitów do Biblioteki Seminaryjnej w Warszawie nie mają więc w sobie nic zagadkowego. Wiadomo, jaki kataklizm spowodował zmianę właściciela książek, wiadomo, jak technicznie zostało to wykonane. Z tych samych powodów, tym samym sposobem, a także w tym samym czasie część zabrzescianów dostała się do Biblioteki Uniwersyteckiej w Warszawie (wówczas Biblioteki Głównej). Ale znaczna ich część dotarła do zbiorów uniwersyteckich drogą zupełnie nieoczekiwana: poprzez Bank Polski.

Bank Polski to instytucja powstała w $1828 \mathrm{r}$. jako jedna $z$ inicjatyw ministra skarbu Królestwa Polskiego Franciszka Ksawerego Druckiego-Lubeckiego i familii Łubieńskich, dla ożywienia życia gospodarczego kraju. Miał on dużą i ciekawą bibliotekę o wyraźnie polskim charakterze, aczkolwiek było w niej wiele współczesnych publikacji zagranicznych. Jej zakres tematyczny znacznie wykraczał poza ramy biblioteki podręcznej tego typu instytucji. Poza książkami ekonomicznymi i prawniczymi niezbędnymi dla pracowników Banku biblioteka zawierała dzieła historyczne, geograficzne, filozoficzne, a nawet literaturę klasyczną. Z chwilą ustąpienia ze stanowiska prezesa Banku Henryka Łubieńskiego księgozbiór przestał się rozwijać. Przyszły kłopoty z cenzurą, przenoszenie ksiąg do wciąz innych, niewłaściwych pomieszczeń, próby sprzedaży. Wreszcie w 1899 r. nastąpiło przekazanie księgozbioru Bibliotece Uniwersyteckiej w Warszawie ${ }^{83}$. 
Badania proweniencyjne starych druków prowadzone w Bibliotece Uniwersyteckiej wykazały w kolekcji odziedziczonej po Banku Polskim dużą liczbę zabrzescianów. Wszystkie one, prawie bez wyjątków, mają bardzo dokładnie zatarty zapis karmelitów warszawskich: „Conventus Varsaviensis Carmelitarum Discalceatorum" i tylko kontury dużych liter pozwalają domyślić się właściwego tekstu. Natomiast nie zawsze wycierano dopiski przed i po nazwisku naszego bibliofila, dokonane ręką bibliotekarza karmelitów warszawskich. Nigdy też prawie nie było zatarte nazwisko Zabrzeskiego. Widać wyraźnie, że chciano zniszczyć tylko znaki własnościowe karmelitów (il. 2 i 3).

Można wysunąć hipotezę, że ktoś wynosił potajemnie książki z biblioteki klasztoru karmelitów i przekazywał (pewnie sprzedawał), gdzie się dało. Zabrzesciana bankowe są owocem tej działalności. Trudno bowiem przypuścić, by zakonnicy w latach 30-tych XIX wieku sami rozsprzedawali lub nawet rozdawali swój ksiegozbiór, a zresztą gdyby tak było, nie potrzebowano by tak starannie zacierać śladów ${ }^{84}$.

Uwagę zwraca fakt, że część książek z kolekcji bankowej ma w prawym górnym rogu karty tytułowej maleńkimi, równymi, o charakterystycznym kroju cyferkami napisaną sygnaturę, która pozwala stwierdzić rękę Kajetana Kwiatkowskiego. Niektóre z tych książek są zresztą przez niego podpisane imieniem i nazwiskiem.

Kajetan Kwiatkowski, w młodości szambelan Stanisława Augusta, polityk i literat, członek Towarzystwa Przyjaciół Nauk, był zamiłowanym bibliofilem. Zgromadził znaczny księgozbiór, wysoko oceniany przez specjalistów. Podziwiali go m.in. Bentkowski, Lelewel, Estreicher ${ }^{85}$. Wiadomo, że zespół starych druków Banku Polskiego pochodzi prawie wylącznie z księgozbioru Kwiatkowskiego, który sprzedał swą kolekcję Bankowi w 1838 roku.

Rękopisy Kwiatkowskiego nabył już w 1821 r. Tytus Działyński do swojej biblioteki w Kórniku. Związana z tym jest przykra rozprawa, jaką miał Kwiatkowski przed komisją do badania spraw spadkowych Dominika Radziwiłla w związku z podejrzeniem, a wlaściwie udowodnieniem mu zabrania pewnej części rękopisów z Biblioteki Nieświeskiej, w której był zatrudniony w latach 1804-1810 ${ }^{86}$. Ten skądinąd zasłużony dla kraju człowiek okazał się bezwzględny, gdy szło o pozyskiwanie obiektów do własnych zbiorów. Można przypuścić, iż właśnie on był jednym $z$ głównych odbiorców książek wynoszonych od karmelitów.

Potem, jak wspomniano, sprzedał swoje książki w 1838 r. Bankowi Polskiemu, a księgozbiór Banku wpłynął w 1899 r. do Biblioteki Uniwersyteckiej w Warszawie. W ten sposób spotkały się w BUW zabrzesciana „bankowe" z tymi, które dostały się tu po kasacie klasztoru w 1864 r. Część księgozbioru karmelitów warszawskich przekazana w 1864 r. Bibliotece Seminaryjnej znajduje się w niej do dziś, jakkolwiek i ona poniosła duże straty podczas II wojny światowej.

Księgozbiór Biblioteki Seminaryjnej pod kątem obecności w nim zabrzescianów został przebadany w całości, natomiast księgozbiór uniwersytecki - tylko w większej części. Badania proweniencyjne nie są zakończone i - zważywszy wielkość księgozbioru - będą prowadzone jeszcze przez lata. Nie należy jednak spodziewać się w pozostałej do przejrzenia części więcej niż kilku czy kilkunastu pozycji. Wniosek taki nasuwa się z paru powodów. 
Po pierwsze, zdecydowana większość dotychczas ujawnionego księgozbioru Zabrzeskiego w Bibliotece Uniwersyteckiej pochodzi z włączonego w końcu XIX w. zbioru Banku Polskiego, którego zasób XVI-iXVII-wieczny pod względem proweniencyjnym przebadano $w$ calości. Po drugie - przebadano również caly stary zasób szesnastowieczny BUW, a druki XVI wieku stanowią większość w księgozbiorze Zabrzeskiego ( $w$ Bibliotece Seminaryjnej-ok. 75\%, w Uniwersyteckiej-ok. $85 \%$ ). Ewentualne przybytki księgozbioru Zabrzeskiego moga pochodzić z dalszych badań nad drukami XVII wieku starego zasobu, których pod względem zapisów własnościowych przejrzano ok. $20 \%$. Można więc w przyszłości spodziewać się najwyżej kilkunastu pozycji z biblioteki Zabrzeskiego, co nie powinno zasadniczo zmienić obrazu jego kolekcji.

Rozesłana kwerenda wykazała ponadto, że książki Zabrzeskiego znajdują się $w$ kilku innych bibliotekach polskich. Według obecnej wiedzy stan zabrzescianów w naszych książnicach wygląda następująco:

Biblioteka Uniwersytecka w Warszawie

Biblioteka Metropolitalnego Seminarium

Duchownego Rzymsko-Katolickiego w Warszawie

Wojew.Bibl.Publ.im.H. kopacińskiego w Lublinie

Biblioteka Zakł.Nar.im.Ossolińskich we Wroctawiu

Biblioteka Publiczna m.st. Warszawy

Razem

$\begin{array}{rr}231 \text { dziel } & 170 \text { wol. } \\ 222 \text { dziela } & 148 \text { wol. } \\ 4 \text { dziela } & 4 \text { wol. } \\ 2 \text { dziela } & 2 \text { wol. } \\ 2 \text { dzieła } & 3 \text { wol. } \\ 461 \text { dziel } & 328 \text { wol. }\end{array}$

Ponadto R. Kotula opisuje jeszcze jedną pozycję ze zbiorów Zabrzeskiego, a mianowicie Stanisława Niegoszewskiego panegiryk na cześć Zygmunta III Wazy ${ }^{87}$. Nie wiadomo, gdzie teraz znajduje się ten egzemplarz, nie ma go we wrocławskiej bibliotece Ossolineum, być może pozostał we Lwowie. Ostatecznie więc można powiedzieć, że w posiadaniu Zabrzeskiego znajdowały się na pewno 462 dzieła w 329 woluminach.

Należy wymienić jeszcze jeden ślad Biblioteki Zabrzeskiego. Ks. Ludwik Zalewski w swej pracy o bibliotece Seminarium Duchownego w Lublinie, opisując zbiory kanoników regularnych w Kraśniku, wspomina o kilku książkach z proweniencją Karola Zabrzeskiego, o których nie wiadomo, kiedy wpłynęły do biblioteki klasztoru $^{88}$. Po kasacie $w 1864$ r. biblioteka kraśnicka, zgodnie z rozporządzeniem rządu rosyjskiego, została przekazana do seminarium $w$ Lublinie, acz $z$ opóźnieniem i w stanie niekompletnym. W bibliotece Seminarium Lubelskiego książek Zabrzeskiego obecnie nie ma.

Jeden z egzemplarzy Biblioteki Publicznej m.st. Warszawy przeszedł od Zabrzeskiego poprzez bibliotekę karmelitów do Ludwika Korotyńskiego, zmarłego w 1919 r. dziennikarza i literata warszawskiego, współpracownika "Gazety Warszawskiej”, "Tygodnika Powszechnego" i wielu innych czasopism. Zapis karmelitów jest tu wyraźnie wydrapany, a więc droga książki przypomina koleje losu tych egzemplarzy, które dostały się do Banku Polskiego.

Drugi egzemplarz ma całkowicie zamazany zarówno zapis Zabrzeskiego, jak i karmelitów. 
Podobnie jest $z$ dwoma z czterech egzemplarzy przechowywanych w Bibliotece Publicznej im. H. Łopacińskiego w Lublinie. Zapisy karmelitów są tu wydrapane lub zamazane, a jako kolejny właściciel występuje tym razem doktor teologii Paweł Szymański, kanonik kapituły chełmskiej obrządku grecko-katolickiego, profesor Uniwersytetu Warszawskiego, a potem Akademii Duchownej, historyk kościoła unickiego $^{89}$. Był on $w$ latach 1810-1817 profesorem chełmskiego seminarium duchownego i książki, nabyte zapewne w Warszawie, przekazał uczelni, w której kiedyś nauczal, ponieważ obie pozycje mają pieczątki w języku rosyjskim stwierdzające ich przynależność do biblioteki seminarium chełmskiego.

Trzeci z egzemplarzy lubelskich nie ma innych proweniencji poza zapisami Zabrzeskiego i karmelitów, a czwarty dziedziczą po karmelitach dwie znane postaci życia kulturalnego i społecznego Lubelszczyzny. Są to kolejno: Andrzej Edward Koźmian, zmarły w 1864 r. literat, publicysta i polityk zamieszkały w majątku Piotrowice w Lubelskiem i Jan Stefan Kowerski, zmarły w 1935 r. prawnik i działacz społeczny, zamieszkały w Pulawach.

Spośród egzemplarzy zabrzescianów należących do Ossolineum jeden dostał się poprzez Jana Januszowskiego, podkomorzego Iwowskiego z początku XIX w., do Biblioteki Poturzyckiej Dzieduszyckich, drugi był własnością Stanisława Wronowskiego, radcy trybunału we Lwowie, ekscentrycznego zbieracza, który stare oprawy ksiag oklejał niebieskim papierem.

Tak w dużym skrócie przedstawiają się losy spuścizny książkowej Karola Zabrzeskiego. Oczywiście, poszczególne egzemplarze mogą jeszcze wypłynąć tu i ówdzie, nie wszystkie bowiem biblioteki prowadzą badania proweniencyjne, a i z wyżej wymienionych nie wszystkie przebadały swoje zbiory do końca.

\section{CHARAKTERYSTYKA KSIĘGOZBIORU}

Rozdział niniejszy jest próbą charakterystyki omawianej biblioteki od strony treści zgromadzonych w niej ksiąg ${ }^{90}$.

Można w zbiorze tym wyróżnić kilka głównych działów obejmujacych jego większą część, kilka zdecydowanie mniejszych oraz pojedyncze książi z bardzo różnych dziedzin. Procentowy udział poszczególnych działów w zachowanym księgozbiorze przedstawia się następująco:

$\begin{array}{lc}\text { Teksty literackie i komentarze } & 18 \% \\ \text { Gramatyka, leksykografia, podręczniki retoryki } & 18 \% \\ \text { Teologia, literatura religijna } & 17 \% \\ \text { Medycyna } & 14 \% \\ \text { Filozofia } & 13 \% \\ \text { Matematyka i astronomia } & 8 \% \\ \text { Historia, geografia } & 7 \% \\ \text { Prawo } & 3 \% \\ \text { Varia (magia, pedagogika, polityka chronologia i in.) } & 2 \%\end{array}$




\section{Teksty literackie i komentarze}

Książki z zakresu literatury pięknej stanowią jedną z dwu największych grup księgozbioru. Są to na ogół prace z epoki rozwiniętego już humanizmu, radko wydane wcześniej niż ok. połowy XVI w., z komentarzem, przedmowami, indeksami. Zwraca uwagę duża liczba wydań szkolnych. Być może służyły one jako warsztat pracy w czasie krótkiej kariery wykładowcy uniwersyteckiego ich właściciela.

Najobficiej reprezentowana jest grecka literatura starożytna. Wymienić tu można przede wszystkim trzy antologie: piękną edycję Henri Estienne'a a zawierającą zbiór utworów starożytnych poetów epickich ${ }^{91}$, następnie dzieła „poetarum veterum Ecclesiasticorum" zebrane przez Georga Fabriciusa ${ }^{92}$, a wreszcie zbiór utworów poetów starożytnych greckich i rzymskich w siedemnastowiecznym wydaniu z Douai ${ }^{93}$.

Kolekcja zawiera ponadto kilka wydań Homera, dzieła Hezjoda, Kallimacha, Charaktery Teofrasta ${ }^{94}$, ErotikaParteniosa z Nikai ${ }^{95}$, Opowieści efeskie Ksenofon$\mathrm{ta}^{96}$, Argonautyki Apolloniosa z Rodos ${ }^{97}$. Nie brak również Historii etiopskiej, nieprzerwanie popularnej przez kilka wieków opowieści Heliodora z Emezy. Zabrzeski miał ją w trzech egzemplarzach, przy czym pierwszym właścicielem jednego z nich był król Zygmunt August ${ }^{98}$.

Jedynym przedstawicielem literatury pięknej średniowiecza jest Theodorus Prodromus ze swoją, ocenianą jako bardzo mierna, opowieścią Rhodantis et Dosiclis amorum libri wydaną w Paryżu w $1625 \mathrm{r}^{99}$

Oprócz dzieł literackich księgozbiór Zabrzeskiego zawieral dość dużo komentarzy do literatury starożytnej. Większość z nich to dzieła uczonych renesansowych, glównie protestantów. Wymienić tu można komentarze do Epinikiów Pindara pióra Benedikta Aretiusa ${ }^{100}$, czy F. Portusa prolegomena do tragedii Sofoklesa ${ }^{101}$.

Dość bogato reprezentowana jest epistolografia, gatunek odziedziczony po starożytności, bardzo popularny w czasach renesansu.

Poza listami pisarzy starożytnych - Cycerona i Arystotelesa - można wymienić Epistolarum libri Christophe'a Longueil'a, jednego ze znakomitych latynistów XVI wie$\mathrm{ku}^{102}$, trzy centurie listów Domiminique'a Baudier'a, protestanckiego literata francuskie$\mathrm{go}^{103^{\prime}}$, a także listy Joachima Camerariusa wydane po jego śmierci przez synów ${ }^{104}$.

Oracji zachowalo się w księgozbiorze warszawskiego dygnitarza stosunkowo niewiele: ze starożytnych jedynie mowy Isokratesa w trzech wydaniach i kilka mów Cycerona, ponadto Orationes funebres wspomnianego już Joachima Camerariusa ${ }^{105}$.

W dziale tym dominuje literatura starożytna, ale nie znajdujemy w nim podstawowych pozycji tejże literatury. Nie ma np. tragedii Ajschylosa, Eurypidesa, do Sofoklesa są tylko komentarze. Nie ma prawie utworów rzymskich poetów z czasów Augusta: Horacego, Wergiliusza, Owidiusza.

Wśród publikacji nowożytnych bardzo niewiele jest dzieł literatury pięknej w ścisłym tego slowa znaczeniu. Uderza brak wielkich dzieł literatury światowej: utworów Petrarki, Rabelais'a, Tassa, Ariosta, a także zupełny brak literatury pięknej w języku polskim.

Jeśli w przypadku literatury światowej działać mogła bariera językowa, bo od czasów Renesansu wielkie dzieła tej literatury tworzone były w językach narodo- 
wych, to w przypadku książek polskich można tylko przypuszczać, że nie zostały one prekazane karmelitom i uległy zaczytaniu.

Wymienić można również kilka zbiorów sentencji i przysłów, bardzo popularnych w szesnastym i siedemnastym wieku. A więc słynne Adagia Erazma z Rotterdamu ${ }^{106}$, wybór sentencji z zachowanych fragmentów dziet piećdziesięciu autorów komediowych starożytności wydany w Bazylei u Oporina ${ }^{107}$ czy Apophthegmata ex Plutarcho et aliis scriptoribus selecta wydane przez Johanna Possela ${ }^{108}$.

\section{Gramatyka, leksykografia, retoryka}

Na podstawie księgozbioru Zabrzeskiego można sądzić, że te dziedziny wiedzy były dla niego szczególnie interesujące. Różnego typu podręczniki gramatyki czy retoryki, słowniki i podobne publikacje stanowią jeden z największych działów jego biblioteki.

Podręczniki i publikacje z zakresu gramatyki można podzielić na trzy grupy: dzieła dotyczące hebrajskiego, greki i łaciny.

Podręczników hebrajskiego nie ma wiele, ale ich ciężar gatunkowy jest duży. Wśród autorów spotykamy znane nazwiska: Nikolasa Kleynaertsa, flamandzkiego filologa z I połowy XVI w., Michaela Neandra, ucznia i przyjaciela Melanchtona, Davida Woldera.

Ze starożytnych podręczników gramatyki greckiej występuje tylko jedna publikacja: to, co pozostało z dziel wielkiego językoznawcy cesarstwa rzymskiego Apolloniosa Dyskolosa ${ }^{109}$. Spośród mistrzów nowożytnych miał Zabrzeski między innymi prace dwóch stynnych filologów greckich, uciekinierów przed Turkami z Konstantynopola - Teodora Gazy i Demetriosa Chalkondylasa, którzy kulturę grecką przeszczepili na grunt zachodnioeuropejski. Z prac uczonych późniejszych - Guillaume'a Budé, jednego z pierwszych we Francji miłośników i znawców greki - jego fundamentalne dzieło „Commentarii linguae Graecae"110, dwa wydania podręcznika wspomnianego już Kleynaertsa ${ }^{111}$, podręczniki greki wszechstronnego Pierre'a de La Ramée (Petrus Ramus) ${ }^{112}$ oraz niemieckiego lekarza i językoznawcy - Martina Rulanda ${ }^{113}$. Wymienić tu jeszcze można rzadkich w bibliotece Zabreskiego autorów katolików: Francisco Vergarę, Hiszpana z Toledo i jezuitę Jacoba Gretsera, erudytę niemieckiego, którego prace szybko uległy zapomnieniu. Rzuca się w oczy również brak twórczości Polaków w tej dziedzinie, chociaż poziom filologii klasycznej był w Polsce XVI w. wysoki. Nie ma publikacji Jakuba Górskiego, Stanisława Grzepskiego, Benedykta Herbesta ani nawet największego z nich Andrzeja Patrycego Nideckiego.

Podręczników gramatyki łacińskiej jest w księgozbiorze niezbyt wiele. Na uwagę zasługuje dzieło Alda Manucjusza młodszego - Orthographiae ratio opracowany przez niego system ortografii i interpunkcji łacińskiej, ksiązka wydana we własnym wydawnictwie weneckim ${ }^{114}$.

Bardzo licznie reprezentowane są słowniki. Między innymi spotykamy leksykon Hezychiusza z Aleksandrii, zawierający objaśnienia rzadkich słów występujących $\mathrm{u}$ autorów greckich ${ }^{115}$, stownik synonimów Martina Rulanda, zawierający tak 
potrzebne w pracy autorów renesansu „locutionum et phrasium elegantiae"116 oraz pięć słowników greckołacińskich: słownik Conrada Gesnera, bazylejskie wydanie, dumnie zaanonsowane na karcie tytułowej „supra omnes editiones" ${ }^{117}$, słownik Jean Crespin'a - przez niego opracowany i wydany w jego wydawnictwie w Genewie $^{118}$, bazylejski - Waldera ${ }^{19}$ i dwa bezautorskie, wydane przez Lemaire'a w Genewie i Cratandra w Bazylei ${ }^{120}$.

Jest kilka prac z zakresu nauczania retoryki. Przede wszystkim starożytnego mistrza Isokratesa Phraseologia Graecolatina opracowana przez Michaela Neandra, dwa bliskie w czasie wydania Oporina ${ }^{121}$. Ponadto P. Victoriusa komentarz do klasycznego dzieła Demetriosa z Faleronu (IV-III w. p.n.e.) o wymowie, florenckie wydanie Giuntów ${ }^{122}$. Wszechstronnego Melanchtona Elementorum rhetorices libri duo wydane w Bazylei u Oporina ${ }^{123}$. Związanego z Lutrem i Melanchtonem reformacyjnego teologa i filologa Paula Perdixa (Rebhuna) zwroty łacińskie służące do „kształtowania" języka ${ }^{124}$, a także nauczyciela wymowy w Strasburgu - Melchiora Juniusa - szkolny podręcznik retoryki ${ }^{125}$.

\section{Teologia}

Jest to jeden z najbardziej rozbudowanych działów jego biblioteki. Zestaw książek wskazuje na człowieka zainteresowanego problematyką religijną, światłego, nie stroniącego od myśli reformacyjnej, a przeciwnie, bardzo nią zainteresowanego.

Miał oczywiście kilka wydań Biblii. Zasługuje na uwagę wittenberskie wydanie Kluga z 1529 r. siedmiu psalmów pokutnych w języku hebrajskim, z filologicznym przekładem łacińskim, pozycja obecnie w Polsce unikalna ${ }^{126}$. Ponadto Pieśń nad pieśniami po hebrajsku, z łacińskim tłumaczeniem Sebastiana Munstera ${ }^{127}$. Tematyka bezpośrednio biblijna występuje w utworze szesnastowiecznego lekarza i poety neołacińskiego Michaela Bartha. Jego dystychy „de patriarchis... prophetis... apostolis", przetłumaczone na grekę w lipskim wydaniu Steinmanna z 1581 r., również są w Polsce unikatem ${ }^{128}$.

Ostało się w księgozbiorze 10 egzemplarzy katechizmu, ale nie zachował się wśród nich ani jeden katolicki. Wymienić tu trzeba przede wszystkim 3 pozycje autorstwa Lutra: 2 egzemplarze katechizmu mniejszego w edycji Oporina z 1567 r. i wydanie magdeburskie w opracowaniu Georga Majora. Poza tym katechizm szkolny w opracowaniu Melanchtona oraz Rudimenta fidei Christianae Kalwina, w greckim thumaczeniu Henri Estienne'a, wydane przez jego brata Roberta w Genewie, a także Martina Rulanda, lekarza z Freisingen, katechizm po grecku, wydany w 1565 r. w Augsburgu. Osobną pozycję stanowi katechizm wierszem po grecku i łacinie niemieckiego hellenisty Lorenza Rhodomanna ż 1626 r. Trzy egzemplarze są bezautorskie: wydanie Akademii Wittenberskiej z 1570 r., wydanie z La Rochelle z przedmową Henri Estienne'a z 1588 r. i greckie, bardzo uszkodzone, co nie pozwala na ustalenie edycji ${ }^{129}$. Wieloletnia praca w konsystorzu wymagała oczywiście dobrej znajomości zasad herezji, ale czy tylko to było powodem zgromadzenia takiej liczby katechizmów innowierczych?

Posiadał Zabrzeski także sporo pism autorów wczesnochreścijańskich. Należy do nich bardzo popularne w swoim czasie dzieło, noszące często zbiorowy 
tytuł Auctores historiae Ecclesiasticae, zawierające początki dziejów Kościoła chrześcijańskiego ${ }^{130}$. Wymienić tu można również Euzebiusza z Cezarei egzegezę Nowego Testamentu (Evangelicae demonstrationes i Evangelicae praeparationes) ${ }^{131}$, jak również dzieła bardzo popularnego nieznanego autora $z \vee$ w., który podawał się za Dionizego Areopagitę.

Mial również pisma ojców Kościoła. Homilie po grecku w zbiorowym wydaniu Davida Hoescheliusa ${ }^{132}$, wysoko oceniane pod względem literackim listy papieża Grzegorza Wielkiego w bardzo wczesnym wydaniu paryskim Geringa i Rembolta z $1508 r^{133}{ }^{133}$, kilka mów złotoustego kaznodziei - św. Jana Chryzostoma ${ }^{134}$. Również bardzo zawsze popularne, mające dziesiątki wydań dzieło o tematyce etycznej - Soliloquia - uchodzące do niedawna jeszcze za wytwór pióra św. Augustyna, opracowane przez jednego z czołowych przedstawicieli myśli Renesansu, Ludovica Vivesa, wydane w $1541 \mathrm{r}$. we Wroclawiu przez Winklera, rektora szkoły przy kościele św. Elżbiety ${ }^{135}$.

Do dzieł o tematyce chrześcijańskiej pióra autorów starożytnych i wczesnośredniowiecznych zaliczyć można jeszcze poetycki utwór Nonnosa z Panopolis. Ten żyjący $w \vee$ w. twórca eposu o Dionizosie, jako jedyny swój utwór związany z religią chrześcijańska napisal heksametrem parafrazę Ewangelii św. Jana, wydaną u Plantyna w $1589 r^{136}$

Dzieł największych współczesnych reformatorów Kościoła spotykamy tu niewiele. Z prac teologicznych Lutra, Melanchtona, Kalwina w księgozbiorze znajdują się obecnie jedynie opracowane przez nich katechizmy. Jest natomiast znaczna ilość dzieł innych autorów reformacyjnych. W kolekcji spotykamy prace Théodore'a de Bèze, Davida Chytraeusa, Caspara Peucera, Jacoba Herbranda i innych. Są to dzieła treści dogmatycznej, etycznej, nierzadko o charakterze polemicznym, publikowane przeważnie w XVI w.

Śladem stynnej w swoim czasie polemiki Erazma z Rotterdamu z Lutrem na temat wolności woli są dwie broszury Erazma: De libero arbitrio i Hyperaspistes. Zabrzeski miał obydwa utwory wydane w pierwszej polskiej prawdziwie nowoczesnej oficynie Hieronima Wietora, w latach dwudziestych szesnastego wieku ${ }^{137}$. To, że Wietor opublikował je bardzo szybko po ukazaniu się pierwszego wydania, dowodzi żywego zainteresowania społeczności polskiej europejskimi dyskusjami religijnymi; świadczy też oczywiście o sprawności zawodowej drukarza.

Utrwalona została również w księgozbiorze Zabrzeskiego inna polemika, a właściwie jej fragment, tym razem dotyczący spraw polskich. Fricius, sive de maiestate Sedis Apostolicae, to atak Stanisława Orzechowskiego z pozycji kontrreformacyjnych na Andrzeja Modrzewskiego - Frycza. Druk wydano w 1562 r. w Krakowie lub Kolonii. Brak karty tytułowej i kart poczatkowych tekstu nie pozwala na identyfikację wydania ${ }^{138}$.

Wśród autorów katolickich w kolekcji Zabrzeskiego wymienić można jeszcze dwóch z nielicznych w dochowanym zbiorze Polaków: Stefana Damalewicza i Samuela z Lublina. Autorstwa Damalewicza miał Zabrzeski żywoty arcybiskupów gnieźnieńskich, wydane w 1649 r. u Elerta w Warszawie ${ }^{139}$. Pióra Samuela z Lublina, profesora Akademii Krakowskiej, autora rozpraw teologicznych w duchu tomistycznym, jest Summula casuum w wydaniu kolońskim Crithiusa z 1635 r. ${ }^{140}$ 
Z publikacji reprezentujących Kościół wschodni znajdujemy dzieło XIV-wiecznego arcybiskupa Salonik Nila Cabasilasa-De primatu papae Romani, polemiczne w stosunku do Kościoła łacińskiego ${ }^{141}$ i brewiarz obrządku greckiego, późnoszesnastowieczne wydanie rzymskie ${ }^{142}$.

Uderza zupelny brak literatury dewocyjnej i niewielki stosunkowo procent publikacji katolickich. Ten katolik, ściśle nawet zawodowo związany z katolicyzmem (jego praca w konsystorzu), działający w latach rozkwitu kontrreformacji, zebrał księgozbiór daleki od ortodoksyjności, lansujący myśli i idee oficjalnie wyraźnie zwalczane. Nawet przy założeniu, że katolickie książki sensu stricto dewocyjne przed przekazaniem karmelitom albo potem uległy zaczytaniu, nie zmieni to bardzo charakteru zbioru: liczba dzieł nieortodoksyjnych jest zdumiewająca.

\section{Medycyna}

Medycyna jest czwartym co do wielkości działem w bibliotece Zabrzeskiego. Zasób jego książek medycznych jest więc stosunkowo duży, stanowi 14\% całego księgozbioru. Nie jest to jednak fakt zaskakujący. Zainteresowanie medycyną w Polsce XVI i XVII w. było ogromne. Poczynając od dworu królewskiego, kończąc na mieszczaństwie, kolekcjonowano dzieła medyczne i często wypowiadano się na temat zdrowia ludzkiego nie tylko w literaturze naukowej, ale i pięknej. Powstawało wiele publikacji w duchu nauki średniowiecznej opartej na Hipokratesie, Galenie i Avicennie, jak również opracowań nowoczesnych, uwzględniając świeżo zdobytą, opartą na sekcji zwłok, wiedzę o ciele czlowieka.

Jednakże dzieł największych luminarzy medycyny, tych którzy spowodowali, że wiedza ta posunęta się napród milowymi krokami, nie znajdujemy w jego księgozbiorze. Nie ma w nim prac Vesaliusa, Ambroise'a Paré, Michaela Serveta czy Williama Harveya, prezentujących ich genialne odkrycia.

Są natomiast liczne prace największych autorytetów medycznych starożytności. Zachował się w jego zbiorach fragment wydania dzieł wszystkich Hipokratesa z 1595 r., jak również jego dzieła wybrane i wybór aforyzmów w opracowaniu Jakuba Curiona ${ }^{143}$. Galen reprezentowany jest jeszcze bogaciej: dzieła wszystkie po grecku wydane w Bazylei u Cratandra, dzieła wszystkie po łacinie w bazylejskiej edycji Frobena i dzieła wybrane, również w wydaniu bazylejskim Isingrina ${ }^{144}$.

$Z$ ciekawostek wymienić trzeba "Theriaka" i "Alexifarmaka”, dwa poematy treści medycznej wspomnianego już Nikandra, poety greckiego z II w. p.n.e. ${ }^{145}$ Jeden zawiera opisy jadowitych wężów i sposoby ich odstraszania, drugi - opisy zatruć i sposoby ich leczenia.

Poza starożytnymi zbierał Zabrzeski prawie wyłącznie prace lekarzy szesnastowiecznych. Z publikacji uczonych o znanych nazwiskach można tu wymienić: renesansowego erudyty Conrada Gesnera Apparatus et delectus simplicium medicamentorum - cenne dzieło z zakresu farmacji ${ }^{46}$, trzy pozycje slawnego Montana, profesora wysoko cenionego fakultetu medycznego w Padwie (między innymi komentarze do Galena i Avicenny) ${ }^{147}$ oraz równie sławnego Antonia Musy Brasavoli dzietko farmaceutyczne De medicamentis ${ }^{148}$. 
Czy dotarła do warszawskiego prawnika sława tych ludzi? Być może. Wydaje się jednak, że w przypadku medycyny najważniejsza była dla niego tematyka. Nabywał publikacje mało znanych autorów, jak np. Jacoba Gengera, skromnego lekarza z Eichstädt - Consilium de pestis regimine ${ }^{149}$, czy Johanna Philippa Lonera z Naumburga, autora dwóch traktatów, z których jeden - poświęcony objawom i metodom leczenia apopleksji - miał w swych zbiorach ${ }^{150}$. Obydwie prace traktują o konkretnych, spotykanych wówczas często chorobach. Kompilacyjne dziełko Sebastiana Austriusa, mało znanego lekarza strasburskiego, poświęcone chorobom dziecięcym, choć niezbyt atrakcyjne wydawniczo, mogło być bardzo dla niego interesujące ze względu na liczne potomstwo ${ }^{151}$.

Lista ta mogłaby być kontynuowana. Przegląd książek lekarskich Zabrzeskiego nasuwa wniosek, że jego księgozbiór medyczny, jakkolwiek zawierał również prace teoretyczne, w dużej mierze nastawiony był na służenie doraźną pomocą w przypadku konkretnych dolegliwości jego właściciela, rodziny, może przyjaciół.

\section{Filozofia}

Zainteresowania filozoficzne Zabrzeskiego wydają się zwiazane z jego studiami, a potem krótkim stażem dydaktycznym na wydziale artium. Zgodnie z ówczesnym programem studiów poczesne miejsce w jego kolekcji zajmował Arystoteles. Miał więc Zabrzeski: dziela wybrane Stagiryty w kolońskim wydaniu Birckmanna w thumaczeniu loachima Perionia ${ }^{152}$; Organon $w$ trzech wydaniach bazylejskich: greckie Isingrina i dwa grecko-łacińskie Oporina ${ }^{153}$; Politica z oficyny Elzevirów ${ }^{154}$, Oeconomica wydane u Vögelinów w Lipsku ${ }^{155}$. Z dzieł uchodzących wtedy zá arystotelesowe - Mechanica i Problemata ${ }^{156}$.

Miał też znaczną ilość oddzielnie wydanych komentarzy do pism Arystotelesa: niemieckich teologów protestanckich - Daniela Cramera, Rudolfa Gocleniusa, Nicolausa Selneccera, Johanna Velcuriona, francuskiego erudyty Pierre'a de La Ramée, włoskiego filozofa z Padwy - Giuseppe Zabarelli.

Dzieł Platona Zabrzeski nie miał albo nie zachowały się w jego bibliotece; nie znajdujemy też $w$ niej teraz żadnego omówienia dzieł wielkiego filozofa. $Z$ prac filozofów neoplatońskich zachował się w zbiorze komentarz do Aurea carmina Pitagorasa, pióra Hieroclesa ${ }^{157}$.

Z prac filozoficznych starożytnych Greków znajdujemy dzieła Diona Chrysostoma, Epikteta, historyka-filozofa Plutarcha. Można wspomnieć listy przypisywane Falarisowi, tyranowi Akragas (Agrigento) z VI w. p.n.e. - przykład popularnej literatury filozoficznej.

Interesujące jest jedno z nielicznych poloników: pseudo-Herenniusa Enarratio in Metaphysica Simone Simonide interprete, druk Akademii Zamojskiej z 1604 r., edycja nieukończona, bez karty tytułowej i dwóch ostatnich kart tekstu ${ }^{158}$.

Starożytnych Rzymian reprezentują w kolekcji Zabrzeskiego Cycero i Julian Apostata.

Ze wspótczesnych opracowań z zakresu etyki napotykamy Melanchtona, Joachima Camerariusa, Martina Haynecciusa, Johanna Thomasa Freigego. Z zagadnień logicznych - tegoż Freigego, Rudolfa Gocleniusa. Z dialektyki - prace Hospiniana, 
Johanna Sturma i jezuity Pedra de Fonseca. Z dziedziny metafizyki - dzieła kardynała Gaspare Contariniego, Benedicta Pereiry i Pedra Hurtado de Mendoza.

\section{Matematyka i astronomia}

Większość książek matematycznych to podręczniki i opracowania ogólne.

Jest więc klasyczne dzieło Euklidesa, żywe jeszcze w XIX w. - Elementa geometriae, opracowane przez Johanna Vögelina i Georga Peurbacha ${ }^{159}$; Ramusa Proemium mathematicum ${ }^{160}$; szkolne opracowanie Adama Lonicera Brevis et utilis arithmeticae introductio ${ }^{161}$; cenionego przez współczesnych Conrada Dasypodiusa Mathematica ${ }^{162}$ (do naszych czasów dochował się w kolekcji tylko t. 2) i kilka innych.

Bogaciej reprezentowana jest astronomia. Ilość publikacji astronomicznych dwukrotnie przewyższa matematyczne. Z dzieł klasycznych znajdujemy tu między innymi: neoplatończyka Diadocha Proklosa trzy wydania dzieła De sphaera ${ }^{163}$, Jana de Sacrobosco Libellum de sphaera z przedmowa Melanchtona ${ }^{164}$ (wittenberskie wydanie Kluga z 1538 r.). Ze współczesnych - prace astronomiczne Wilhelma Adolfa Scriboniusa, Josiasa Simlera, Corneliusa Valeriusa, Sebastiana Winshema, Conrada Dasypodiusa. Nie brak horologium we wczesnoszesnastowiecznym wydaniu Giunty.

Dodać można jeszcze Aratusa - greckiego poety z III w. sławny poemat dydaktyczny o treści astronomicznej - Fainomena - źródło wiedzy o astronomii jeszcze w średniowieczu ${ }^{165}$.

Zestaw prac astronomicznych jest obfitszy i mniej podręcznikowy niż matematycznych. Częściej trafiają się tu dzieła nowsze i częściej, poza opracowaniami ogólnymi, spotykamy publikacje dotyczące problemów szczegółowych, jak np. Giovanniego Pontano Liber de meteoris ${ }^{166}$, czy jedyna tu praca zwiazana $z$ astrologia - Jean Baptiste Morina Ad australes et boreales astrologos pro astrologia restituenda epistolae - wydana w Paryżu w $1628 r^{167}$

\section{Historia, geografia, biografie}

Galerię historyków starożytnych w zbiorach warszawskiego prawnika otwiera - wg porządku chronologicznego - ojciec historii, wielki Herodot. Pisma jego miał Zabrzeski w dwóch edycjach grecko-łacińskich ${ }^{168}$. Miał ponadto Bityńczyka Arriana Flawiusza z II w. wczesne bazylejskie wydanie dzieła o Aleksandrze Macedońskim. Oczywiście, niezmiennie przez kilka wieków popularne Vitae parallelae Plutarcha w siedemnastowiecznym wydaniu strasburskim ${ }^{169}$, a także Appiana z Aleksandrii ocalałe fragmenty dziejów Rzymu ${ }^{170}$.

Wśród starożytnych opisów geograficznych wymienić można m.in. bardzo wysoko przez potomnych oceniane Pauzaniasza Decem regionum veteris Greciae descriptio (w polskim thumaczeniu Wędrówki po Helladzie ${ }^{\dagger 71}$ ) i dzieło Dionizjosa Periegety służące jako podręcznik geografii w starożytności i średniowieczu - De situ Orbis (Opis świata zamieszkałego) ${ }^{172}$, jak również trzy współwydane prace geograficzne uczonych starożytności - Arriana, Plutarcha, Strabona - we wczesnym bazylejskim wydaniu Hieronima Frobena ${ }^{173}$. 
Z prac historyków nowożytnych na uwagę zasługuje piękna edycja Wechelusa z 1600 r. - Rerum Hungaricarum scriptores varii- przykład popularnej w XVI i XVII w. antologii dzieł historycznych dotyczących jakiegoś jednego kraju czy narodu. Książka jest notowana przez Estreichera, ponieważ zawiera kilkudziesięciostronicowe opracowanie Filipa Kallimacha De rebus gestis a Vladislao Polonorum atque Hungarorum rege libri tres ${ }^{174}$.

Drugie polonikum, to Reinholda Heidensteina De bello Moscovitico commentariorum libri sex, wydane w Oficynie Łazarzowej w 1584 r., publikacja propagandowa, mająca służyć czytelnikowi krajowemu i zagranicznemu informacją o polityce króla Stefana Batorego i kanclerza Jana Zamoyskiego ${ }^{175}$.

Na wymienienie zasługuje również włoskiego lekarza Paola Giovia historia powszechna, obejmująca czasy mu współczesne, czyli I połowę XVI w. Niezwykle popularna, często wznawiana. Zabrzeski mial wydanie florenckie Torrentina z lat 1550-1552 ${ }^{176}$. Można wspomnieć też dzieło historyczno-obyczajowe Martina Crusiusa Germanograeciae libri sex ${ }^{177}$, a także José de Acosta, prowincjała jezuitów w szesnastowiecznym Peru - opis tego kraju pt. De natura Novi Orbis libri duo ${ }^{178}$.

$Z$ prac biograficznych trzeba wymienić Pedra de Ribadeneira Catalogus scriptorum religionis $S J$ - parokrotnie przedrukowywany leksykon członków Towarzystwa Jezusowego parających się piórem. (Zabrzeski miał wydanie Plantyna z 1613 r.) ${ }^{179} \mathrm{Z}$ problematyki wschodniej - Paula Oderborna, kaznodziei ryskiego, życiorys Iwana Groźnego wydany w Wittenberdze u spadkobierców Cratona ${ }^{180}$.

\section{Prawo}

Mimo że Zabrzeski jako pracownik konsystorza, burmistrz i sekretarz królewski napotykać musiał stale w swej działalności problemy z dziedziny prawa, ksiąg o tematyce prawniczej znajduje się w jego bibliotece zdumiewająco mało.

Prawo kanoniczne reprezentowane jest nader skromnie, dwiema tylko pozycjami. Pierwsza z nich, to praca De litterali ac mystica regularum iuris canonici interpretatione Paola Carrarii, wydana w Bolonii w $1617 \mathrm{r} .{ }^{91}$ Druga, to pozycja czysto praktyczna: Formularium instrumentorum ad usum Curiae Romanae, liońskie wydanie z $1534 \mathrm{r}^{182}$

Prawo cywilne przedstawia się bogaciej. Z kodeksu Justyniana spotykamy wprawdzie tylko Institutiones, ale za to w interesującym, jednym z dwu najwcześniejszych, wydaniu, przygotowanym przez cenionego prawnika Vigliusa Zuichemiusa $^{183}$. Miał ponadto komentarz Johanna Schneidewina do tychże Institutiones i komenatarz Diodora Tuldeniusa do całego kodeksu Justyniana. Był również w posiadaniu klasycznej w tej dziedzinie pozycji: Benedicta Carpzova (jednego z nielicznych w księgozbiorze autorów współczesnych Zabrzeskiemu) Decisionum Saxoniarum pars prima-secunda, wydanej w latach 1652-1654, jeszcze za życia autora $^{184}$. Do naszych czasów dochowały się w zbiorach warszawskiego burmistrza cz. 2 i 3 . Wspomnieć jeszcze można komentarze do prawa miejskiego Commentarii in ius Lubecense również współczesnego Zabrzeskiemu syndyka ze Stralsundu - Davida Meviusa (tylko cz. 3, wydana w Lipsku w 1643 r.) ${ }^{185}$. Ciekawy jest klocek introligatorski zawierający m.in. pierwsze wydanie Garrona In titulum 
Pomponii De origine iuris... comentaria..., Gilberta Cognata De legalis studiis ratione $\mathrm{i}$ duże fragmenty Corpus iuris civilis ${ }^{186}$. Pozostałe publikacje to kilka drobniejszych prac dotyczących różnych szczegółowych problemów prawnych.

Książki prawnicze stanowią 3\% całości księgozbioru. Inne są też tu proporcje wieku XVI i XVII niż w pozostałych działach. Ksiażki XVII-wieczne to ok. $70 \%$ publikacji prawniczych w dochowanym księgozbiorze Zabrzeskiego. Więcej wśród nich dzieł współczesnych autorowi, wiele pozycji czysto praktycznych, mogących służyć pomocą w rozstrzyganiu konkretnych problemów prawnych. Tym bardziej jednak dziwi ubóstwo tego warsztatu pracy. Można tylko przypuszczać, że książki prawnicze stanowiły rodzaj biblioteki podręcznej i -stale używane - uległy w końcu zniszczeniu, dlatego w większości nie zostały przekazane karmelitom.

\section{Magia, pedagogika, polityka, chronologia}

W księgozbiorze Zabrzeskiego, o którym można powiedzieć, że jest w ogólnym wyrazie renesansowy, nie mogło zabraknąć magii, tej „,szczególnej formy renesansowego mistycyzmu"187. Ówcześni entuzjaści magii opierali swą wiedzę na księgach powstalych rzekomo w starożytnym Egipcie ${ }^{188}$.

Zabrzeski miał dzieła trzech słynnych przedstawicieli tej dziedziny: Jamblicha, ucznia Porfiriusza, filozofa i matematyka, prace o misteriach egipskich (wydanie rzymskie z połowy XVI w.) ${ }^{189}$; słynnego humanisty francuskiego Jean Bodina, który interesował się Talmudem, Kabałą, magią - pracę De magorum demonomania libri IV (wydanie bazylejskie z 1581 r.) ${ }^{190}$ oraz równie stynnego Johanna Reuchlina, filologa, oskarżonego o judaizm przed kolońskim fakultetem teologicznym - De arte cabalistica libri tres (wydane w Hagenau w 1530 r.) ${ }^{191}$.

$Z$ zakresu pedagogiki sensu stricto wymienić trzeba 4 wydania Plutarcha De liberis educandis ${ }^{192}$ (wieloegzemplarzowość jest częsta w tym księgozbiorze), a z autorów nowożytnych - teologa luterańskiego Davida Chytraeusa Regulae studiorum seu de ratione et ordine discendi ${ }^{193}$ oraz profesora języka hebrajskiego i matematyki na uniwersytecie w Lejdzie - Rodolfa Snella De ratione discendi et exercendi logicam per analysin ${ }^{194}$.

Ponadto w księgozbiorze znajdują się pojedyncze egzemplarze reprezentujące inne dziedziny wiedzy, jak polityka, ekonomia czy chronologia.

\section{ZAKOŃCZENIE}

Ujawniony księgozbiór jest fragmentem, znacznym zapewne, lecz nie wiemy jak dużym, biblioteki zebranej przez Karola Zabrzeskiego. Nie wiemy, ile dzieł zawierała ta biblioteka za życia właściciela, ani jak bogate były poszczególne działy wymienione w rozdziale IV. Wiele wskazuje na to, że np. dział prawniczy był nieporównywalnie większy niż w chwili obecnej. Niewiele wiemy też o tym, w jaki sposób kolekcja była gromadzona. Dlatego wszelkie ogólniejsze wnioski na temat tego interesującego księgozbioru muszą mieć charakter ostrożnie formułowanych supozycji.

Nieliczne notatki na kartach ksiażek pozwalają przypuszczać, że narastał on stopniowo, gromadzony przez właściciela latami ${ }^{195}$. Wydaje się, że Zabrzeski był 
bardziej bibliofilem niż uczonym i zbierał książki nie tylko ze względu na ich treść, ale był również wrażliwy na tego rodzaju uroki poszczególnych egzemplarzy, jak piękna szata zewnętrzna czy słynne nazwiska poprzednich właścicieli. Wieloegzemplarzowość kolekcji potwierdza jeszcze to wrażenie. Zwraca uwagę zgromadzenie w zbiorze dużej liczby doskonałych edycji najpierwszych oficyn europejskich: Frobena, Estienne'a, Plantyna, Manucjuszów, a wiele nazwisk poprzednich właścicieli należy do powszechnie znanych.

Jakkolwiek burmistrz warszawski nie miał własnego superekslibrisu ani ekslibrisu i kazał książki swe oprawiać skromnie w gładki pergamin, jego kolekcja zawiera wiele ciekawych zapisów własnościowych i wiele pięknych opraw.

Nie szukał rzadkości bibliograficznych: większość jego książek to publikacje znane i popularne w Europie. Nie wszystkie jednak były popularne w Polsce - jego księgozbiór, nawet w dzisiejszej uszczuplnej postaci, zawiera pewną liczbę książek obecnie unikalnych w kraju.

Jak wygląda zbiór Zabrzeskiego taki, jaki jest obecnie, na tle księgozbiorów współczesnych mu Polaków? Zależy to oczywiście od ich stanu społecznego i profesji. Mieszczanie Poznania, Krakowa i Lwowa w swych bibliotekach miewali od kilku do kilkuset woluminów. Siedemnastowieczni rajcy krakowscy, a więc przedstawiciele patrycjatu wielkiego miasta, posiadali przeciętnie po 40 tomów $^{196}$. Inwentare mieszczan poznańskich z początku XVII w. wykazują po kilka, wyjątkowo po kilkanaście książek ${ }^{197}$. Zmarły w 1704 r. lekarz toruński Wacław Durosch miał zbiór liczący 220 dzieł ${ }^{198}$. Podobno znacznych rozmiarów był wspomniany w literaturze piękny księgozbiór zmarłego w 1682 r. Stanisława Baryczki, podobnie jak Zabrzeski obywatela Warszawy i sekretarza królewskiego, ale ta biblioteka nie jest dotychczas opracowana.

Oczywiście, bywały i księgozbiory bardzo duże. Żyjący o pół wieku wcześniej od Zabrzeskiego Salomon Rysiński, zmarły w 1625 r. filolog i erudyta, miał 822 tomy ${ }^{199}$. Współczesny Rysińskiemu Szymon Szymonowicz przekazał Akademii Zamojskiej 1428 dzieł, ale był on uczonym i pisarzem wyższej znacznie rangi niż Rysiński, a biblioteka jego gromadzona była przez dwa pokolenia ${ }^{200}$. Ponad 1700 dzieł zawierał księgozbiór Hieronima Pinocciego, zwierzchnika Zabrzeskiego w kancelarii królewskiej - ale Pinocci górował nad Zabrzeskim pozycją społeczną, zamożnością i szerokością zainteresowań ${ }^{201}$. Bardzo duży był też księgozbiór Łukasza Opalińskiego, uczonego magnata, który miał wielkie fundusze i również nie zaczynał zbierania od zera ${ }^{202}$.

Księgozbiory Szymonowicza i Rysińskiego, których gromadzenia zaprzestano pół wieku wcześniej (obaj przeżyli tylko pienwszą ćwierć XVII wieku), a także z uwagi na wyraźne filologiczne i literackie zainteresowania ich właścicieli, są zdecydowanie szesnastowieczne. Natomiast porównanie zbiorów Zabrzeskiego ze znanymi księgozbiorami gromadzonymi tylko w XVII w. (niektórzy mieszczanie poznańscy, Durosch, Pinocci, Opaliński) nasuwa nieodparcie wrażenie wyraźnej nienowoczesności jego biblioteki. Oczywiście książka szesnastowieczna żyła długo i do osiemnastego wieku była dość powszechnie w użyciu, Zabrzeski jednak wyjątkowo wyraźnie preferowal ksiażkę dawniejszą we wszystkich, poza prawem, galęziach wiedzy ${ }^{203}$. 
Ponadto rzuca się w oczy brak w zbiorze dzieł polskich. Nawet, jeśli przyjmie się hipotezę, że literatura piękna nie została przekazana karmelitom, lecz uległa rozproszeniu, uderza brak polskiej książki naukowej, np. z zakresu matematyki czy filologii klasycznej, które to dziedziny wiedzy stały wysoko w Polsce XVI wieku, nie mówiąc już o braku polskiej książki historycznej (poza dziełem Heidensteina, które jest tu wyjątkiem). Zwraca również uwagę, przy dużym nagromadzeniu książek z różnych dziedzin teologii, zupełny brak literatury dewocyjnej.

Brak tego typu książek nasuwa przypuszczenie, że do karmelitów dotarła tylko część księgozbioru - książki, których nie rozebrano przed przekazaniem do klasztoru. Nie dotarhy natomiast do biblioteki klasztornej rzeczy poczytne oraz o doraźnej wartości użytkowej: literatura piękna w języku polskim, historia Polski, literatura dewocyjna i prawnicza.

W zbiorze jest dużo wydań szkolnych. Część z nich mogła służyć swemu właścicielowi jako warsztat pracy w jego krótkiej karierze wykładowcy uniwersyteckiego. Część - to być może podręczniki jego dzieci.

Wreszcie zaskakuje mnogość dzieł autorów różnowierczych zgromadzonych w księgozbiorze tego wieloletniego pracownika konsystorza. Pisarze katoliccy są tu bardzo skromnie reprezentowani. Można próbować tłumaczyć to faktem, że bardzo wiele autorytetów naukowych - autorów publikacji z XVI w. - to innowiercy, a Zabrzeski cenił i gromadził książki szesnastowieczne. Na ogół jednak ludzie jego stanu w jego czasach ograniczali się do posiadania książek ultrakatolickich i to niewielu. Zabrzeskiemu musiała co najmniej nie przeszkadzać ideologia książek innowierczych. Wspomniany wcześniej fakt służenia swą osobą w charakterze świadka na ślubie luteranina wskazuje na jego dużą tolerancyjność i życzliwość wobec ludzi o innej orientacji religijnej. Przypuszczalnie miał szersze horyzonty myślowe i glębsze zainteresowania intelektualne od większości współczesnych równych mu stanem.

Księgozbiór i okruchy informacji na temat życia Zabrzeskiego, jakie udało się zebrać, wydobywają z zakamarków naszej historii postać niebanalną i ciekawą bibliotekę o znacznej wartości historycznej.

\section{Przypisy}

${ }^{1}$ Kartoteka Działu Historii do 1795 r. Muzeum Historycznego m.st. Warszawy (skrót: Kartoteka Muz. Hist. W-wy) nr 8444: Liber baptisatorum (skrót: Lib. bapt.) 1649-1659, s. 216 oraz nr 9629: Lib. bapt. $1649-1659$, s. 265.

${ }^{2}$ Statuta nec non liber promotionum philosophorum ordinis in Universitate studiorum Jagellonica ab anno 1402 ad annum 1849. Ed. Josephus Muczkowski, Cracoviae, 1849, s. 313.

${ }^{3}$ I.St. Szlachetka, Hortus academicus..., Cracoviae 1644, k. G ${ }_{2}$ verso.

${ }^{4}$ Rps BJ sygn. 220 sub anno 1644. Wiadomość otrzymana dzięki uprzejmości prof. L. Hajdukiewicza.

${ }^{5}$ Kartoteka Muz. Hist. W-wy nr 8455: Lib. bapt. 1649-1659, s. 222.

${ }^{6}$ ibidem nr 8455: Lib. bapt. 1649-1659, s. 217; nr 16727: Lib. bapt. 1669-1678, s. 458; nr 5577; Liber copulatorum (skrót: Lib. cop.) 1673-1689, s. 92.

7 ibidem nr 11951: Lib. cop. 1657-1660, s. 271.

${ }^{8}$ ibidem nr 8484: Lib. bapt. 1649-1659, s. 222. 
${ }^{9}$ ibidem nr 4626, 5612, 18273, 18534: Lib. bapt. 1649-1659.

${ }^{10}$ W końcu grudnia 1653 Zofia z Gomerów jest wdową po Antonim Teście, ale nie nazywa się jeszcze Zabrzeska (Kartot. Muz. Hist. W-wy nr 7002: Lib. bapt. 1649-1659, s. 166). 29 III 1658 odbył się chrzest córki Karola Zabrzeskiego i Zofii z Gomerów - również Zofii (Kartot. Muz. Hist. W-wy nr 10738: Lib, bapt. $1649-1659$, s. 296 ,

${ }^{11}$ Lustracja z 1658 r. wykazuje, że Karol Zabrzeski mieszka w domu przy Świętojańskiej 9 z żoną i pięciorgiem dzieci. (Źródka do dziejów Warszawy..., Warszawa 1963, s. 140, 206). 318.

${ }^{12}$ Kartoteka Muz. Hist. W-wy nr 4209, 4492, 12133: Lib. bapt. 1659-1668 s. 7, 40, Lib. cop. VI, s.

${ }^{13}$ Roczne salarium burmistrza w czasach kazimierzowskich wynosiło 100 zł, co można zestawić np. z czterystuzlotową pensją pisarza radzieckiego. (A. Kersten, Warszawa kazimierzowska, Warszawa 1971, s. 161).

${ }^{14}$ Archiwum Glówne Akt Dawnych (skrót: AGAD), Warszawa Ekonomiczne, mikr. nr 536, s. 9. W tym wypadku Zabrzeski nie w pelni poniósł koszta reprezentacji. W protokole z zebrania Rady Miejskiej czytamy, iż ponieważ burmistrz "na drogę i wszystkie koszty tylko zlotych 100" wziąl, uchwalono dodać mu "ex contributione" złotych 300 .

${ }^{15}$ Wskazuja na to tytuly umieszczane przy jego nazwisku w ksieggach parafialnych oraz, expressis verbis, zapis w Metryce Koronnej (AGAD, Metryka Koronna, mikr. nr 213, s. 195-197). Dr E. Opalińskiemu dziękuję za wskazanie mi kilku informacji zawartych w tym źródle.

${ }^{16}$ Acta Nuntiaturae Polonae moderante Henrico Wojtyska, Romae 1990, s. 276. Wiadomość otrzymana dzięki uprzejmości prof. L. Hajdukiewicza.

${ }^{17}$ Przywileje i constitucje sejmowe... roku... M.DC.LXXVI, Kraków 1676, s. 61 -62 oraz Archiwum Polskiej Akademii Nauk (skrót: Archiw. PAN) Materiały J. Wolińskiego, sygn. III-198, teczka 45-47, odpisy diariuszy sejmowych 5. 63(122).

${ }^{18}$ Herbu Zabrzeskich nie podaje K. Niesiecki, wymieniający imiennie Karola Zabrzeskiego jako świeżo nobilitowanego, nie wspomina E. Kuropatnicki, J.S. Borkowski ani cytująca te wszystkie publikacje Encyklopedia Szlachecka. Wśród najnowszych opracowań heraldycznych nazwisko Zabrzeskiego znajduje się w T. 9 Materiałów do biografii, genealogii i heraldyki polskiej (Regestry nobilitacji w Polsce 1404-1794, oprac. Z. Wdowiszewski, Buenos Aires - Sztokholm 1987, 5. 683) również bez podania nazwy herbu.

${ }^{19}$ Tytulu tego nie wymienia też A. Przyboś (Urzędnicy dawnej Rzeczypospolitej XII-XVIII wieku, T. 3. Ziemie ruskie. Zesz. 1. XIV-XVIII w. Wroclaw 1987), ale zaznacza we wstępie, że zestawienie z powodu niedostępności akt jest zrobione tylko na podstawie literatury.

${ }^{20}$ Ch. H. Erndtel, Varsavia physicae illustrata, Dresdae 1730, s. 23.

${ }^{21}$ AGAD, Metryka Koronna, mikr. nr 211, s. 195-197.

22 ibidem, mikr. nr 211, s. 351-352.

23 ibidem, mikr. nr 210 , s. 737.

24 ibidem, mikr. nr 213, s. 61.

${ }^{25}$ AGAD, Warszawa Ekonomiczne, mikr. nr 536, s. 194.

${ }^{26}$ Ciekawe, że kontakty towarzyskie tego czlowieka, tak silnie związanego z katolicyzmem jego praca w konsystorzu) nie ograniczały się do środowiska katolickiego: $30 \mathrm{~V} 1666$ był świadkiem na ślubie luteranina Natana Kolla z Godańska (Kartoteka Muz. Hist. W-wy nr 12133: Lib. cop. VI s. 318).

${ }^{27}$ K. Piekarski, Książka XV-XVI w. w:Kultura staropolska, Kraków 1932, s. 380.

${ }^{28}$ M. SipayHto, Polskie superexlibrisy XVI-XVIII w., Warszawa 1988, s. 6-7.

${ }^{29}$ Prawdopodobnie nie miał superekslibrisu Łukasz Opaliński (por. K. Schuster, Biblioteka kukasza Opalińskiego, Wrodaw 1971, s. 93). Nie miał go tez, jak się zdaje, Stanisław Itowski (kartoteki proweniencyjne BUW). 
${ }^{30}$ Np. pozycje: BUW sygn. 28.20.3.2446; BUW sygn. 28.20.3.2341; BUW sygn, 28.20.2.656.

${ }^{31}$ Francforti 1594, Biblioteka Seminarium Metropolitalnego Duchownego Rzymsko-Katolickiego św. Jana Chrzciciela (skrót BSW) sygn. A.2.33ª adl.

$32 \mathrm{Cl}$. Galenus, Opera omnia..., Basileae 1538, BUW sygn. 28.20.2.211.

33 Opera..., Basileae 1562, BSW sygn. K.9.40.

${ }^{34}$ Aristaenetus, Epistolae Graecae..., Parisiis 1610, BUW sygn. 28.20.3.2446.

${ }^{35}$ Księgozbiór królewski doglębnie omówiony został w pracy A. Kaweckiej-Gryczowej, Biblioteka ostatniego Jagiellona..., Wroctaw 1988. Prof. Gryczowa cytuje 5 wol. należących do Zygmunta Augusta, które znalazły się potem w bibliotece Zabrzeskiego. Nie została podana pozycja szósta: Porphyrius, Eisagoge sive institutiones quinque vocum ad Chrysoarium..., Basileae 1545, BUW Sd.608.528.

${ }^{36}$ Wiadomości dotyczące życia wcześniejszych wlaścicieli książek Zabrzeskiego - jeśli nie jest podane inne źródło informacji - pochodzą z Polskiego Slownika Biograficznego i Historii Nauki Polskiej.

${ }^{37}$ Familiarium colloquiorum opus..., Basileae 1533, BUW sygn. Sd.608.163.

${ }^{38}$ Zob. przyp. 6.

${ }^{39} \mathrm{~K}$ Piekarski, Superexlibrisy polskie od XV do XVIII wieku, Kraków 1929, s. 33.

40 Opus utrumque Homeri lliados et Odysseae..., Basileae 1541, BUW sygn. 28.20.2.380.

${ }^{41}$ Orationes LXXX... (Graece), Venetiis (1551), BUW sygn. 28.20.2.1766.

42 Divinae Scripturae Veteris Novaeque omnia t. 2-3, Argentorati 1526, BUW sygn. Sd.608.886.

${ }^{43}$ Catullus... Tibullus et Propertius, Venetiis 1562, BUW sygn. 28.20.2.1808.

44 1530, BUW sygn. Sd.602.335 adl.

45 Selectarum epistolarum libri quatuor Graecolatini..., Ingolstadii 1602, BSW sygn. L.3.2.

${ }^{46}$ Coloniae 1570, BSW sygn. K.5.53.

${ }^{47}$ Archiwum nacji polskiej w Uniwersytecie Padewskim. Wyd. H. Barycz, t. 1, Warszawa 1971, s. 433.

${ }^{48}$ Tendencja stylizowania gmerków czy innych znaków tożsamości na godła herbowe występuje często w XVI i XVII w. Przykladem może być superekslibris Samuela Nakieiskiego, który z czasem coraz bardziej przypominał Śreniawę. Zob. M. SipayHo, Polskie superexlibrisy XVI-XVIII wieku, Warszawa 1988 , s. 9. 21.

${ }^{49}$ L. Hajdukiewicz, Księgozbiór i zainteresowanie bibliofilskie Piotra Tomickiego, Wrocław 1961, s.

50 Geographia..., Venetiis 1562, BUW sygn. 28.9.8.9.

51 Tubingae 1562, BUW sygn. 28.2.4.6.

52 Basileae 1541, BUW sygn. 28.20.2.636 adl.

${ }^{53}$ I0. de Sacrobosco, Sphaericum opusculum..., Cracoviae 1522, BUW sygn. Sd.614.205 adl.

${ }^{54}$ De morbis muliebribus libri tres..., Venetiis 1588, BUW sygn. Sd.604.883.

${ }^{55} \mathrm{~K}$. Sokołowska-Grzeszczyk, Znaki ksiażkowe lekarzy polskich, „Archiwum Historii Medycyny” t. 44: 1981, zesz. 4, 5. 36.

56 ibidem s. 32.

${ }^{57}$ Chr.G. Jöcher, Allgemeines Gelehrten-Lexicon..., Th. 3, Leipzig 1751.

${ }^{58}$ Basileae 1529, BUW sygn. 28.20.2.654.

${ }^{59} \mathrm{H}$. Barycz, Archiwum nacji polskiej w Uniwersytecie Padewskim. Do druku przygotował..., t. 1, Wroclaw 1971 , s. 371. 
${ }^{60}$ Venetia 1625, BSW sygn. L.3.9.

${ }^{61}$ Nea Diatheke... (Gr.), 1545, BUW sygn. Sd.604.937.

62 J. Bellwon, Księgozbiór Ludwika Ajchlera zachowany w zbiorach Biblioteki Gdańskiej, Libri Gedanenses R. 2-3: 1968-1969, s. 5.

${ }^{63}$ Tertia pars chronici..., Witebergae 1569, BSW sygn. F.17.12.

64 M. Baruch, Ród Fukierów, Warszawa 1922, s. 68.

65 lo. Stobaeus, Sententiae ex thesauris Graeconum delectae..., Tiguri 1543, BUW sygn. Sd.602.1269 adl.

${ }^{66}$ Historiae parentis liber primus..., Lipsiae 1609, BUW sygn. 28.20.3.2411.

67 J.Ch. Adelung, Fortsetzung und Ergänzungen zu Ch. G. Jöchers Allgemeinen Gelehrten-Lexico[!], Bd. 2, Leipzig 1787, szp. 1907; Estr. 18, 93.

${ }^{68}$ Aethiopicorum... libri X..., Heidelbergae 1596, BUW sygn. 28.20.2.1741.

${ }^{69}$ Estr. 25, 392.

${ }^{70}$ Florentiae 1550-1552, BUW sygn. Sd 602-330.

71 „Mercurii Gallobelgici”... tomus primus..., Coloniae Agrippinae 1598, BSW sygn. 0.67.38.

72 A. Boniecki, Herbarz polski. Warszawa 1899, t. 2, s. 122.

${ }^{73}$ Theriaka. Alexifarmaka (Gr.), Parisiis 1557, oraz Aratus Solensis, Fainomena kai diosémeia (Gr.)..., Parisiis 1559, BUW sygn. Sd.604.330-331 adl.

${ }^{74}$ Novum lesu Christi Testamentum..., (Genevae) 1553, BUW sygn. Sd.608.1935 adl.

${ }^{75}$ Estr. 14, 563.

${ }^{76}$ Peri optikes (Gr.)..., Norimbergae 1551, BUW sygn. 28.20.2.434.

${ }^{77}$ K. Piekarski, Superexlibrisy polskie od XV do XVIII wieku, Kraków 1929, s. 11.

${ }^{78}$ Zob. przyp. 16.

${ }^{79}$ Informuje o tym, jak już wspomniano, notatka karmelitów na kartach tytułowych ws zystkich prawie książek pochodzących z ksieggozbioru Zabrzeskiego.

${ }^{80}$ Liber acceptarum et expensarum quotidianarum Conventus Varsaviensis sub titulo B/eati/ss/imae/ V/rginis/M/ariae/..., Archiwum Archidiecezji Warszawskiej, rps nr C.5.6. ADW 39, k. 159 v. Ofiarowywano często kwoty kilkudziecięcioflorenowe, a równa tej darowizna - 500 florenów - pochodziła od książąt Czartoryskich.

${ }^{81}$ Chr.H. Erndtel, Warsavia physice illustrata..., Dresdae 1739, s. 23. Napisanie przez Załuskiego rozdziału "De situ Warsaviae", czego nie był jeszcze pewien Estreicher $(E 34,207)$ potwierdzaja m.in. B. Kryda w pracy „Józef Andrzej Załuski (1702-1744)" w „Pisarze polskiego oświecenia” T. 1. Warszawa 1992, s. 55, i J. Gomulicki w katalogu wystawy "Warszawa drukowana”, Warszawa 1992.

${ }^{82}$ Katalog druków XV i XVI w. Biblioteki Uniwersyteckiej w Warszawie. Wstęp dr Marii Sipayłlo maszyn. s. 14.

${ }^{83}$ Z. Nowakowski, Biblioteka dawnego Banku Polskiego 1828-1885, Warszawa 1936, s. 36.

${ }^{84} \mathrm{O}$ nieporządkach panujących w warszawskiej bibliotece karmelitów po upadku Rzeczypospolitej wspomina Julian Bartoszewicz: „Biblioteka rozleciała się po wszystkich stronach. Księża karmelici narzekają na Czackiego, że bardzo wiele im wyciagną̧ ksiąg i wywiózł potem z Warszawy..." (J. Bartoszewicz, Kościoły warszawskie rzymsko-katolickie opisane pod względem historycznym, Warszawa 1855, s. 123.). Ksiażki od karmelitów wyciągal jednak nie tylko Czacki.

${ }^{85}$ Słownik pracowników książi polskiej, Warszawa 1972, s. 493.

86 J. Zathey, Katalog rękopisów średniowiecznych Biblioteki Kórnickiej, Wrocław 1963, s. XXVII$X X V I I I$. 
${ }^{87}$ R. Kotula, Waściciele rękopisów i starodruków zbiorów wielkopolskich Z. Czarneckiego, Lwów 1929 , s. 106.

${ }^{88}$ L. Zalewski, Biblioteka seminarium duchownego w Lublinie..., Warszawa 1926, s. 191.

${ }^{89}$ Slownik polskich teologów katolickich. Red. ks. H.E. Wyczawski, t. 4, Warszawa 1983, 5. 292-293.

${ }^{90}$ Katalog księgozbioru Karola Zabrzeskiego ukaże się ewentualnie w kolejnych zeszytach "Z badań nad polskimi ksiegozbiorami historycznymi".

91 Poetae Graeci principes heroici carminis, (Genevae) 1566, BUW sygn. 28.20.2.209.

92 Basileae 1564, BUW sygn. Sd 604.538.

93 Anthologia poetica Graeco-Latina... Opera... Petri Halloix..., 1617, BSW sygn. B.128.21.

94 Notationes morum..., Lugduni 1599, BUW sygn. Sd.608.796 adl.

95 De amatoriis affectionibus liber..., Basileae 1531, BUW sygn. Sd.608.995 adl.

${ }^{96}$ Quae extant opera..., Genevae 1581, BUW sygn. 28.20.2.225.

97 Argonauticorum libri IV..., Lugduni Batavorum 1641, BUW sygn. 28.20.3.2456.

98 Historiae Aethiopicae libri decem..., Basileae 1534, BUW sygn. Sd.604.80 adl.

99 BUW sygn. 28.20,3.2464.

${ }^{100}$ Commentarii... in Pindari Olympia, Pythia, Nemea... (Genevae) 1587, BUW sygn. Sd.604.540 adl.

101 In... Sophoclis tragoedias prolegomena..., Morgiis 1584, BUW sygn. 28.20.2.659 adl.

102 Basileae 1570, BUW sygn. 28.12.9.14 ${ }^{b}$ adl.

${ }^{103}$ Epistolarum centuriae tres..., Lugduni Batavorum 1620, BSW sygn. N.50.44.

${ }^{104}$ Epistolarum familiarium lib. VI..., Francofurti 1583, BUW sygn. 28,12.9.1 $4^{\mathrm{a}}$ adl.

${ }^{105}$ Lipsiae 1569, BSW sygn. F.4.30 adl.

100 Adagiorum.. epitome..., Coloniae Agrippinae 1562, BSW sygn. K.2.41.

107 Vetustissimorum... comicorum quinquaginta sententiae... (Ed.) I. Hertelius, Basileae 1560, BUW sygn, 28.20.2.1665.

${ }^{108}$ Witembergae 1595, BUW sygn. 28.20.3.2408 adl.

${ }^{109}$ Bios Apollonion Alechandreos ton grammaticon (Gr.)..., (B.m. XVI w. def.), BSW sygn. K.5.61.

${ }^{110}$ Basileae 1556, BSW sygn. K.10.25

111 N. Clenardus, Institutiones absolutissimae in Graecam linguam..., Coloniae 1545, BSW sygn. K.3.86 adl.; N. Clenardus, Institutiones..., Lugduni 1557, BSW sygn. K.8.67 adl.

112 Grammatica Graeca..., Francofurti 1577, BUW sygn. 28.20.2.1734.

${ }^{113}$ De lingua Graeca... libri V. Tiguri 1556, BSW sygn, K.8.68.

1141566 , BSW sygn. B.91.15.

${ }^{115}$ Dictionarium..., Florentiae 1520, BUW sygn. Sd.602.136 Cim.

${ }^{116}$ Synonyma..., (Genevae) 1585, BSW sygn. B.72.16.

${ }^{117}$ Lexikon (Gr.)... 1562, BSW sygn. K.10.9.

${ }^{118}$ Lexicon Graecolatinum..., 1566, BUW sygn. 28.20.2.650.

${ }^{119}$ Lexicon Graecolatinum..., 1537, BSW sygn. 0.147.8. 
${ }^{120}$ Lexicon Graecolatinum..., 1583, BUW sygn. 28.20.2.667; Lexicon Graecolatinum..., 1532, BSW sygn. K.10.3.

${ }^{121}$ Basileae 1558, BUW sygn. 28.20.2.1782 adl.; Basileae (ok. 1555), BUW sygn. 28.20.2.1785.

${ }^{122}$ Commentarii in librum Demetrii Phalerei de elocutione... 1562, BUW sygn. 28.20.2.430.

123 1574, BSW sygn. N.34.10.

${ }^{124}$ Latine dicendi formulae..., Gorlicii 1545, BSW sygn. K.5.27.

${ }^{125}$ Methodus eloquentiae comparandae..., Nombelgardi 1592, BSW sygn. K.2.75.

${ }^{126}$ Septem psalmi poenitentiales..., BUW sygn. Sd.608.1843 adl.

127 Canticum canticorum.... Basileae 1525. BUW sygn. Sd.608.1841 adl.

${ }^{128}$ Disticha sacra.... BSW sygn. K.3.44 adl.

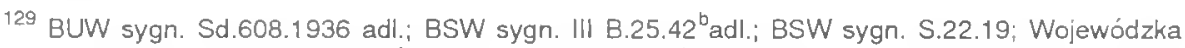
Biblioteka Publiczna im. H. Kopacińskiego w Lublinie (skrót: Łopac.) sygn. 0-16-0-603; BUW sygn. Sd.608.1135; BUW sygn. 28.4.13.22 adl.; BSW sygn. 0.143.9; BSW sygn. S.4.24; BUW sygn. 28.4.13.22 $2^{\mathrm{b}}$ adl.; BSW sygn. P.29.9.

${ }^{130}$ Ekklesiastikes historias... biblia (Gr.)..., Lutetiae Parisiorum 1544, BUW sygn. Sd.602.742.

131 Evangelicae demonstrationes libri X..., Lutetiae 1545; Evangelicae praeparationes libri XV..., Lutetiae 1544, BUW sygn. 28.20.2.219 ${ }^{\mathrm{a}-\mathrm{b}}$ adl.

132 Homiliai theophoron tinon pateron (Gr.)..., Augustae 1587, BUW sygn. Sd.608.1430.

133 BUW sygn. Sd.604.328.

134 Orationes quatuor..., Inglostadii 1595, BUW sygn. 28.20.2.1694 adl.

135 Pseudo-Augustinus Aurelius, Soliloquia..., Vratislaviae 1541, BSW sygn. III.B.25.42 adl.

${ }^{136}$ BUW sygn. Sd.608.2158.

137 De libero arbitrio..., Cracoviae (nie przed 1524); Hyperaspistes... Cracoviae 1526, BUW sygn. 28.2.5.1 $1^{\mathrm{a}-\mathrm{b}} \mathrm{adl}$.

${ }^{138}$ BUW sygn. 28.20.2.1798.

${ }^{139}$ Series archiepiscoporum Gnesnensium..., BUW sygn. 28.20.3.1576.

${ }^{140} \mathrm{BSW}$ sygn. III A.28.28.

${ }^{141}$ Lugduni Batavorum 1595, BUW sygn. 28.20.2.1693 adl.

142 Neon anthologion (Gr.)..., (1598), BUW sygn. Sd.608.1029.

143 Opera omnia... sectio 6-8, Francofurti, BUW sygn. 28.20.2.213; Viginti duo commentarii..., Basileae 1579, BUW sygn. 28.20.2.432; De naturae... hominisq/ue/... morbis, theoria..., Francofurti ad Moenum 1569, BUW sygn. 28.20.2.1670.

144 Opera omnia... P.5., 1538, BUW sygn. 28.20.2.211; Operum... tomus primus (- octavus) T. 6-8, 1542, BUW sygn. 28.20.2.212; Epitome... operum... Basileae 1551, topac. sygn. 0-16-f-78.

145 zob. przyp. 73.

146 Lugduni 1542, BSW sygn. K.5.19 adl.

147 In primi libri Canonis Avicennae primam fen..., explanatio. 2., Venetiis 1557, BSW sygn. K.2.20.

${ }^{148}$ Tiguri 1555, BUW sygn. Sd.608.277 adl.Cim.

${ }^{149}$ Augustae 1535, BUW sygn. Sd.608.279 adl.Cim.

${ }^{150}$ Apoplexiae..., Lipsiae 1596, BSW sygn. K.3.68 adl. 
${ }^{151}$ De infantium sive puerorum morborum... dignotione..., Basileae 1540, BSW sygn. C.11.27 ${ }^{\mathrm{b}}$ adl.

152 Primus/-secundus/ tomus librorum omnium naturalis philosophiae..., 1568, BUW sygn. Sd.604.133.

${ }^{153} 1545$, BUW sygn. Sd.608.524; 1559, Łopac. sygn, 0-16-o-62; 1583, BUW sygn. Sd.608.574.

${ }^{154}$ Politicorum libri XVIII, Lugduni Batavorum 1621, BUW sygn. 28.20.3.2449.

155 1564, BSW sygn. III.B.6.40 a adl.

${ }^{156}$ Parisiis 1599, BUW sygn. Sd.604.275; Francofurti 1585, BUW sygn. Sd.604.246.

157 Commentarius in aurea Pythagoreorum carmina..., Parisiis 1583, BUW sygn. 28.20.2.1635.

${ }^{158}$ BUW sygn. 28,20.3.1361.

${ }^{159}$ Vitebergae 1536, BUW sygn. 28.20.2.1718 adl.

${ }^{160}$ Parisiis 1567, BSW sygn. 0.127.21.

${ }^{161}$ Francofurti 1590, BSW sygn. K.3.58 adl.

162 Volumen 1-ll mathematicum..., Vol. 2., Argentorati 1570, BSW sygn. K.2.66.

${ }^{163}$ Vitebergae 1538, BUW sygn. 28.20.2.1719 adl.; Basileae 1547, BUW sygn. Sd.608.645; Basileae 1561, BUW sygn. Sd.608.684.

${ }^{164}$ BUW sygn. 28.20.2.1721 adl.

165 zob. przyp. 73.

${ }^{166}$ Argentorati 1545, BSW sygn. K.3.71 adl.

${ }^{167}$ BUW sygn. 28.20.3.2400 adl.

${ }^{168}$ Herodoti libri novem..., Basileae 1541, BUW sygn. 28.20.2.421 adl.; Historiae parentis liber..., Lipsiae 1609, BUW sygn. 28.20.3.2411.

169 1630, BUW sygn. 28.20.3.2475.

${ }^{170}$ Romanarum historiarum... fragmenta..., (Genevae) 1592, BUW sygn. Sd.602.261.

171 Lugduni 1577, BUW sygn. Sd.608.598.

172 Lutetiae 1547, BUW sygn. 28.20.2.662.

${ }^{173}$ Arriani et Hanonis periplus..., Basileae 1533, BUW sygn. Sd.604.81 adl.Cim.

${ }^{174}$ Rerum Hungaricarum scriptores..., Francofurti 1600, BUW sygn. Sd.612.199.

${ }^{175}$ BUW sygn. 28.20.2.407.

${ }^{176}$ zob. przyp. 70 .

177 Basileae (1585), BUW sygn. 28.20.2.388.

${ }^{178}$ Coloniae Agrippinae 1596, BSW sygn. K.3.73.

${ }^{179}$ Antverpiae 1613, BUW sygn. 28.20.3.2462.

1801585 , BSW sygn. F.4.30 b ad!.

181 BSW sygn. D.11.10.

182 BUW sygn. 28.3.5 $5^{\mathrm{a}} \cdot 13$

${ }^{183}$ Parisiis 1534, BSW sygn. D.23.41.

${ }^{184}$ Lipsiae, BSW sygn, D.31.22.

${ }^{185}$ BSW sygn. D.27.21 a adl. 
${ }^{186}$ BUW Sd.602.334 adl.

187 T.Klaniczay, Renesans - Manieryzm - Barok. Warszawa 1986.

${ }^{188} \mathrm{C}$. Ronan, The Cambridge illustrated history of the world science, Cambridge 1984, s. 273-276.

${ }^{189}$ De mysteriis Aegyptiorum, Romae 1556, BUW sygn. 28.20.2.638.

190 BSW sygn. F.8.42.

${ }^{191}$ BUW sygn. Sd.602.335 adl.

192 (Francofurti) 1583, BUW sygn. 28.20.2.1658; Stetini (ok. 1590), BUW sygn. 28.20.2.1703 adl.; Witebergae 1607, BSW sygn. R.4.33; Witebergae 1614, BSW sygn. P.51.25.

${ }^{193}$ lenae 1593, BSW sygn. K3.43 adl.

${ }^{194}$ Herbornae 1595, BSW sygn. C.17.27 ${ }^{\mathrm{d}}$ adl.

195 Najpóźniej wydana książka znajdująca się w kolekcji pochodzi z 1661 r. (Ocellus Lucanus, De universi natura..., Amstaeledami, BUW sygn. 28.20.3.1520). O kilka lat późniejsza jest notatka Zabrzeskiego na karcie tytułowej tezaurusa starożytności kościelnych z "Roczników” Baroniusza: „Emptus post mortem D/omi/ni Nicolai Zórawski Carolus Zabrzeski” (BSW sygn. N.37.51). Profesor Akademii Krakowskiej-Mikołaj Źórawski - zmarł w 1665 r., książka mogła być kupiona parę lat po jego śmierci. Zabrzeski gromadził więc książki do późnych lat sześćdziesiątych siedemnastego wieku. Lata siedemdziesiąte (zmarł ok. 1680 r.) są nieudokumentowane.

${ }^{196}$ R. Żurkowa, Księgozbiory mieszczan krakowskich w XVII w. „Rocznik Biblioteki PAN w Krakowie”, R. 13: 1967, s. 21-51.

197 J. Burszta, Cz. Łuczak, Inwentarze mieszczańskie z wieku XVIII z ksiąg miejskich i grodzkich Poznania, t. 1. 1700-1758, Poznaí 1962.

${ }^{198}$ B. Serczykowa, Księgozbiór lekarza toruńskiego Wactawa Duroscha z drugiej połomy XVII wieku. "Zeszyty Naukowe Uniwersytetu Mikołaja Kopernika w Toruniu; Nauki Humanistyczno-Spoleczne" zesz. 39, Nauka o Ksiażce VI, s. 3-32.

199 I. Luksaite, Salomono Risinskio bibliotekos Vilniuje sarasas, w: Is Lietuvos biblioteku istorijos, Vilnius $1985,5.17-45$.

${ }^{200}$ W. Szwarcówna, Biblioteka Szymona Szymonowica, Lublin 1989.

${ }^{201}$ K. Targosz, Hieronim Pinocci - Studium z dziejów kultury naukowej w Polsce w XVII wieku. Wroclaw 1967.

202 K. Schuster, Biblioteka Łukasza Opaliniskiego, Wrockaw 1971.

203 Spis strat wojennych w zbiorze rękopisów BUW wykazuje jedyny, jak dotą, ujawniony rękopis należący do Zabrzeskiego: LaciiPractica, podręcznik lekarski z XVI w., sygn. 5.6.14. H. Kozerska, Strały w zbiorze rekopisów Biblioteki Uniwersyteckiej w Warszawie..., Warszawa 1960, 5. 100. 

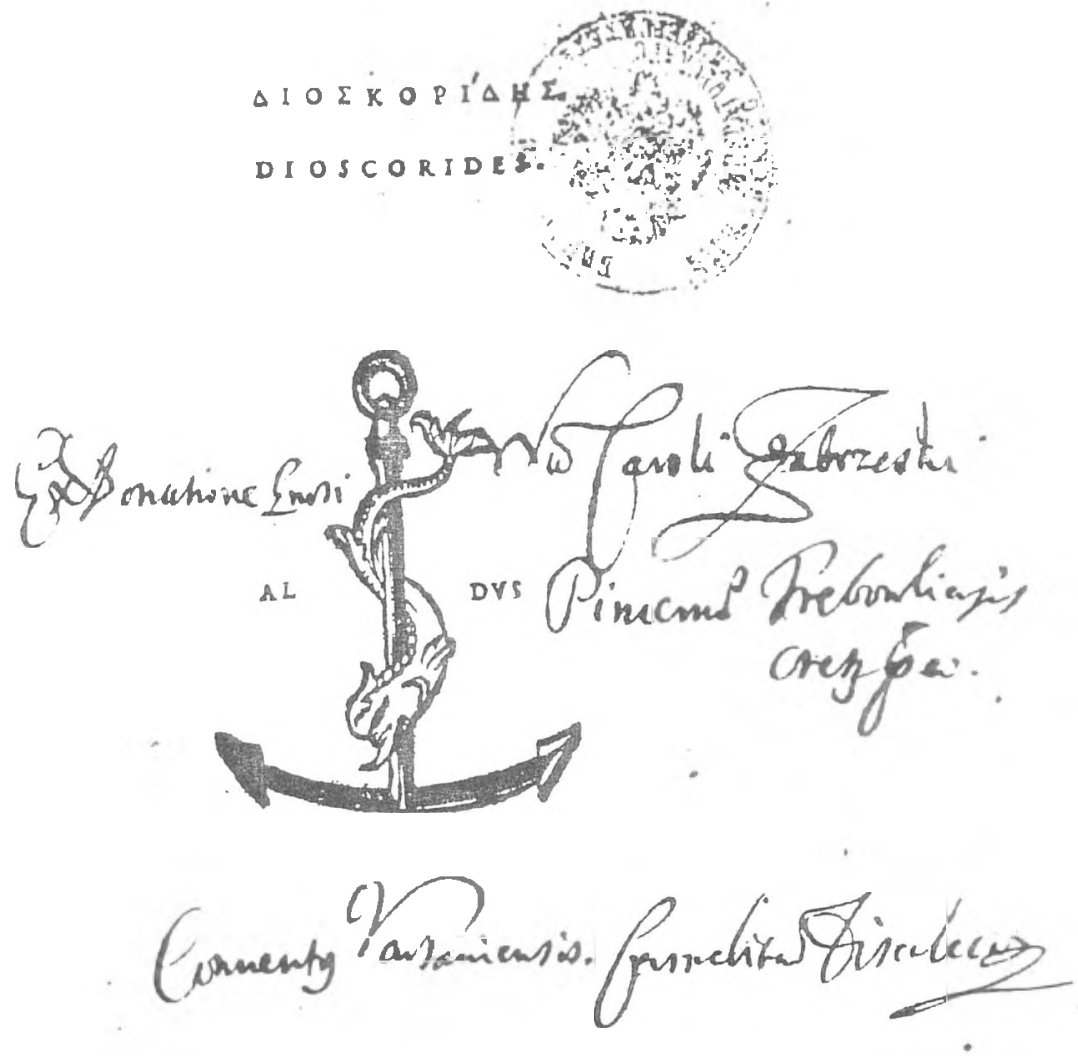

Dioscorides Pedacius - De materia medica libri sex...

Venetiis 1518, BUW 28.20.2.647 


\section{CATALOGVS}

S C R I P T OR V M

RE L I G DO N I \$

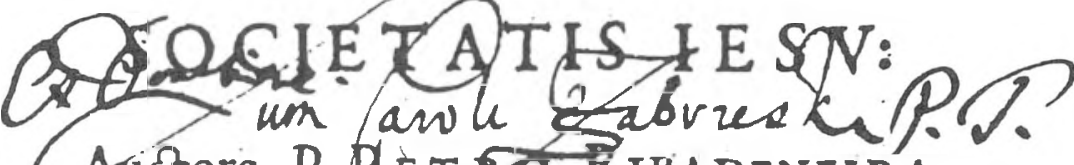
Acictore P.PA T FO RIBADENEIRA Societatis eiufdem Theologo.reh pres

SECVNDA EDIT1O, plurimorum Scriptorumi. acceßione locupletior.
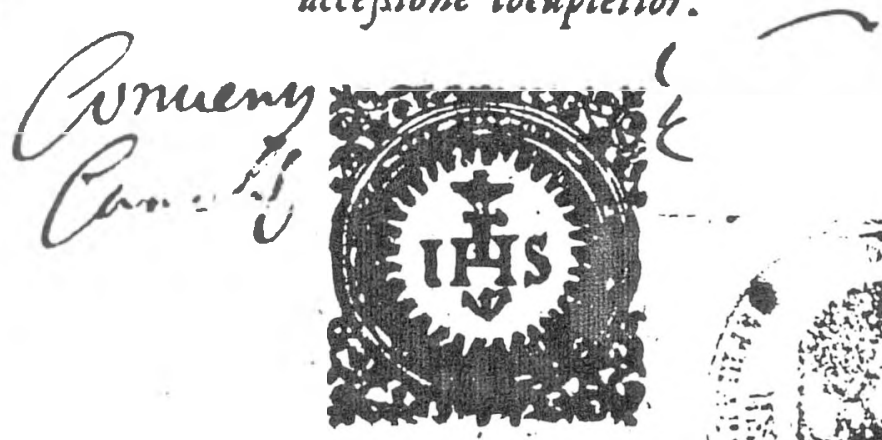

A N T V E R I A ,

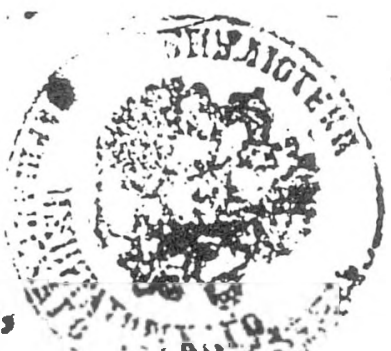

Ex OfFicina Piantintakisit Apud Viduam \& Filios Io. Moreti.

clo. Ioc. XiII.

Cum Prinilegin Regis Ceatholiciot Belgica Principand.

Pedro de Ribadeneira - Catalogus scriptorum religionis Societatis lesu..., Antverpiae 1613, BUW 28.20.3.2462 


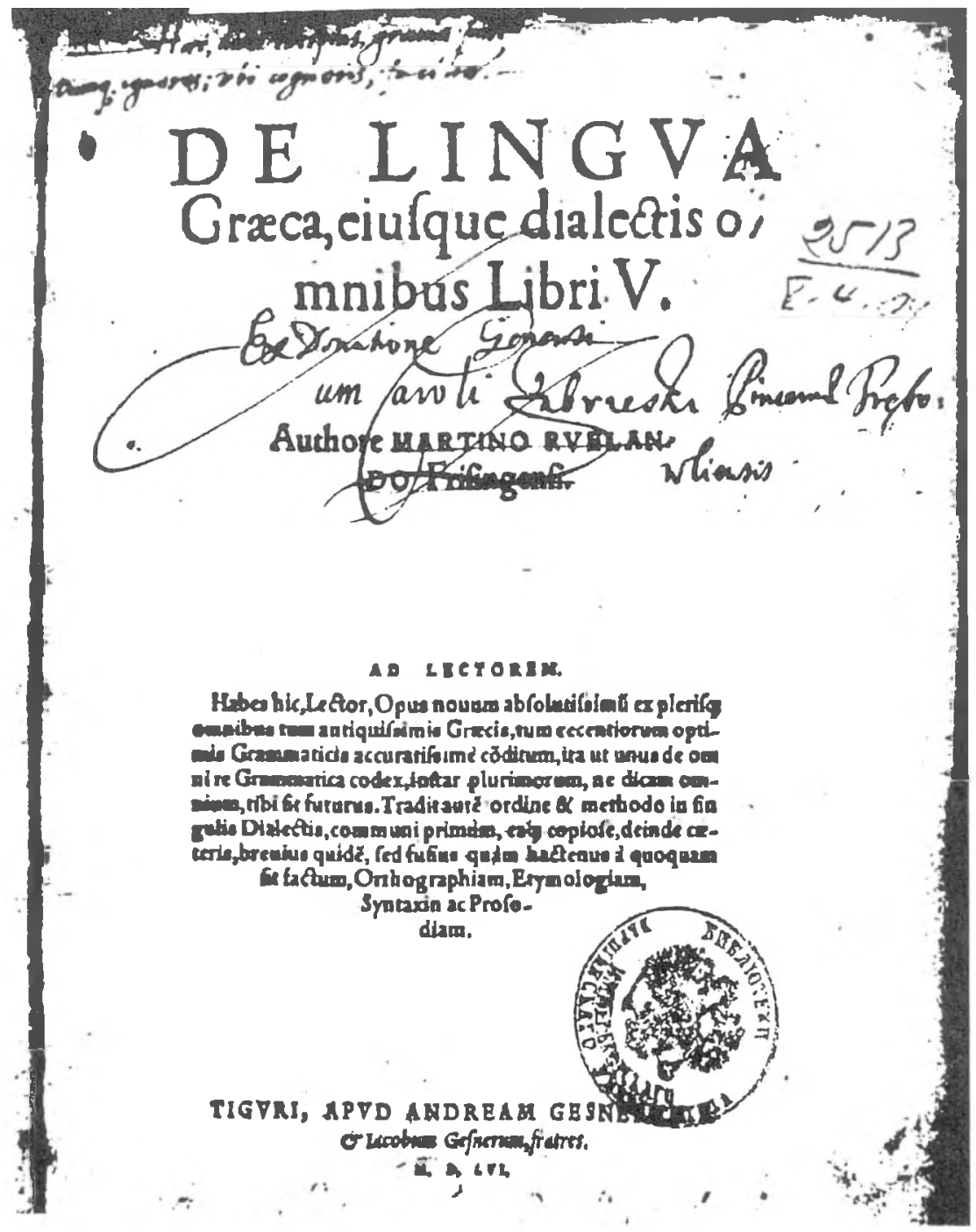

Martinus Rulandus - De Lingua Graecam Tiguri 1556, BUW 28.20.2.656.

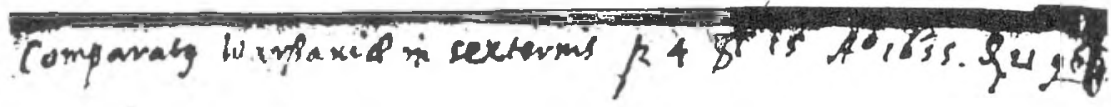

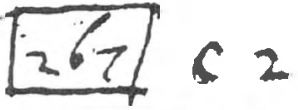

Aristaenefus - Epistolae...,

Parisiis 1610, BUW 28.20.3.2446. 